\title{
Novel Biomarkers in Cardiovascular Disease: A Review
}

\author{
Anna Meiliana ${ }^{1,2 *}$ and Andi Wijaya ${ }^{1,2 *}$ \\ ${ }^{1}$ Post Graduate Program in Clinical Biochemistry, Hasanuddin University, Makassar \\ ${ }^{2}$ Prodia Clinical Laboratory, Jakarta \\ *Address correspondence to this author at: Prodia Clinical Laboratory, Jl. Cisangkuy No.2, Bandung \\ E-mail:anna_m@prodia.co.id, andi_w@prodia.co.id
}

\section{Abstract}

$\mathrm{B}$

ACKGROUND: The investigation of novel circulating serum and plasma biomarkers in patients with cardiovascular disease has been accelerating at a remarkable pace. New markers or tests are often presented too early to the medical profession, potentially leading to overuse and, thus, extra burden and costs to patients, the healthcare industry, and the economy. The challenge for clinicians and medical researchers is how to optimally apply existing and new markers/tests.

CONTENT: Biomarkers are biological parameters that can be objectively measured and quantified as indicators of normal biologic processes, pathogenic processes, or responses to a therapeutic intervention. Typically thought of as disease process screening, diagnosing, or monitoring tools, biomarkers may also be used to determine disease susceptibility and eligibility for specific therapies.

Cardiac biomarkers are protein components of cell structures that are released into circulation when myocardial injury occurs. They play a pivotal role in the diagnosis, risk stratification, and treatment of patients with chest pain and suspected acute coronary syndrome (ACS) as well as those with acute exacerbations of heart failure.

SUMMARY: Active investigation has brought forward an increasingly large number of novel candidate markers but few have withstood the test of time and become integrated into contemporary clinical care because of their readily apparent diagnostic, prognostic, and/or therapeutic utility. With regard to the more novel biomarkers, careful thought is needed with regard to the appropriate target populations for discovery and validation, as well as the criteria used to sort out the contenders from the pretenders.

KEYWORDS: biomarker, cardiovascular disease, atherosclerosis, acute myocardial infarction, heart failure, risk stratification, diagnosis, prognosis.

\section{Introduction}

Cardiovascular diseases (CVD) are the leading cause of morbidity and mortality in the most parts of the world (1). Primary prevention and secondary prevention of CVD are public health priorities (2). Substantial data indicate that CVD is a life course disease that begins with the evolution of risk factors that in turn contribute to the development of subclinical atherosclerosis $(3,4)$. Subclinical disease culminates in overt CVD $(5,6)$. The onset of CVD itself portends an adverse prognosis with greater risk of recurrent events, morbidity, and mortality $(7,8)$.

Clinicians have used additional tools to aid clinical assessment and to enhance their ability to identify the "vulnerable" patient at risk for CVD, as suggested by a recent National Institutes of Health (NIH) panel $(9,10)$.

Biomarkers can indicate a variety of health or disease characteristics, including the level or type of exposure to an environmental factor, genetic susceptibility, genetic 
responses to exposures, markers of subclinical or clinical disease, or indicators of response to therapy. Thus, a simplistic way to think of biomarkers is as indicators of disease trait (risk factor or risk marker), disease state (preclinical or clinical), or disease rate (progression) (11). Accordingly, biomarkers can be classified as antecedent biomarkers (identifying the risk of developing an illness), screening biomarkers (screening for subclinical disease), diagnostic biomarkers (recognizing overt disease), staging biomarkers (categorizing disease severity), or prognostic biomarkers (predicting future disease course, including recurrence and response to therapy, and monitoring efficacy of therapy) (12).

Steady progress in the discovery of new biomarkers and evolution toward more sophisticated clinical applications offer promising possibilities to enhance the care of patients. At the same time, the remarkable increase in the pace of reports about new biomarkers demands even greater attention to their rigorous individual and comparative assessment (13).

Reports of novel biomarkers are abundant in the medical literature. These markers range from simple blood or urine markers to those obtained from, e.g., genomics, proteomics, and imaging techniques; and they vary in accuracy, invasiveness of measurement, and cost. The challenge for clinicians and medical researchers is to optimally exploit existing and new markers or tests.

\section{Biomarker, Discovery and Validation}

Cardiovascular biomarker research efforts have resulted in the identification of new risk factors and novel drug targets, as well as the establishment of treatment guidelines. Government agencies, academic research institutions, diagnostic industries, and pharmaceutical companies all recognize the importance of biomarkers in advancing therapies to improve public health (15).

NIH Definition Working Group established the following working definitions: (1) biomarker-a characteristic that is objectively measured and evaluated as an indicator of normal biological processes, pathogenic processes, or pharmacological responses to a therapeutic intervention; (2) clinical end point-a characteristic or variable that reflects how a patient feels, functions, or survives; and (3) surrogate end point-a biomarker intended to substitute for a clinical end point (16).
The development of CVD biomarkers is challenging for several reasons. As summarized in a recent consensus document $(9,10)$, the patient vulnerable to CVD is likely harboring a triad of abnormalities: vulnerable plaque, vulnerable blood, and vulnerable myocardium. In terms of developing biomarkers, 2 of these 3 components (vulnerable plaque and myocardium) are less directly accessible relative to the third (vulnerable blood).

The aforementioned caveats notwithstanding, 3 parallel developments have revolutionized the field of biomarker discovery. First, the completion of the Human Genome Project (17) and the HapMap Project (18) and the development of microarrays, proteomics, and nanotechnology together provide new avenues for developing exceptionally informative biomarkers of CVD, including high-throughput, highly sensitive, functional assays. Second, the advances in bioinformatics coupled with cross-disciplinary collaborations (eg, of biologists, clinicians, chemists, computer scientists, physicists) have greatly enhanced our ability to retrieve, characterize, and analyze large amounts of data generated by the technological advances noted above. Third, there is increased recognition that diseases arise out of the dynamic dysregulation of several gene regulatory networks, proteins, and metabolic alterations, reflecting complex perturbations (genetic and environmental) of the "system" $(19,20)$.

The development of biomarkers in CVD can be thought of as consisting of 2 potential approaches: the first strategy is "knowledge-based" (deductive method), and the second one is more "unbiased" (inductive strategy). These 2 approaches are complementary rather than mutually exclusive. The knowledge-based strategy relies on a direct understanding of the biological processes that underlie the process of atherosclerosis and the evolution of its sequelae. It may consist of improving existing biomarkers to enhance their performance, or it may comprise designing assays for attractive new candidate markers informed by the biology of the disease process. The unbiased approach involves trolling through tens of thousands of molecules with the use of current technological advances to characterize the biomolecular profile of a stage of the disease (21).

The systems biology tools applied to biomarker discovery investigate the hierarchical organizational of biological information: the gene itself, the mRNA that it produces, the protein coded by the mRNA, biomodules or networks, cells, organs, individuals, populations, and ecologies (19).

Genetic biomarkers are variants in the DNA code that alone or in combination are associated with disease 
susceptibility, disease expression, and disease outcome, including therapeutic responses. Single nucleotide polymorphisms (SNPs; DNA sequence variation when a single nucleotide in the genome sequence is altered) have been evaluated extensively in relation to CVD. The 2 classic complementary approaches used for relating genetic sequence variation to $\mathrm{CVD}$ risk are the linkage approach and the association strategy (22).

The availability of rapid, high-throughput analytical platforms has facilitated molecular phenotyping of disease states by analyzing the transcriptome. The global analysis of gene expression represents a paradigm shift from the traditional single-molecule approach to the evaluation of gene regulatory networks (23-25).

Proteomic approaches to the identification of disease biomarkers rely principally on the comparative analysis of protein expression in normal and disease tissues to identify aberrantly expressed proteins that may represent new biomarkers, analysis of secreted proteins (in cell lines and primary cultures), and direct serum protein profiling (21).
Returning from the bench to the bedside, adoption of a novel biomarker into clinical practice will likely hinge on demonstration that measuring the biomarker's concentration should trigger a clinical intervention, pharmacologic or otherwise. For prognostic biomarkers, patients at higher risk for adverse events will, by definition, be afforded greater absolute risk reduction for a given relative risk reduction from a therapy, and hence a smaller number of these patients will need to be treated to prevent an adverse event. But ideally, pathobiologically relevant prognostic biomarkers would identify a formal treatment interaction with a larger relative risk reduction and thus afford even greater absolute risk reduction.

Novel biomarkers that are true risk factors and faithfully serve as surrogates for clinical outcomes have the potential to markedly diminish the cost of drug development. For example, the ability to detect atherosclerotic plaque destabilization biochemically would allow researchers to screen and identify more easily promising new pharmacotherapeutics that could then be tested in larger and more expensive phase III trials (26).

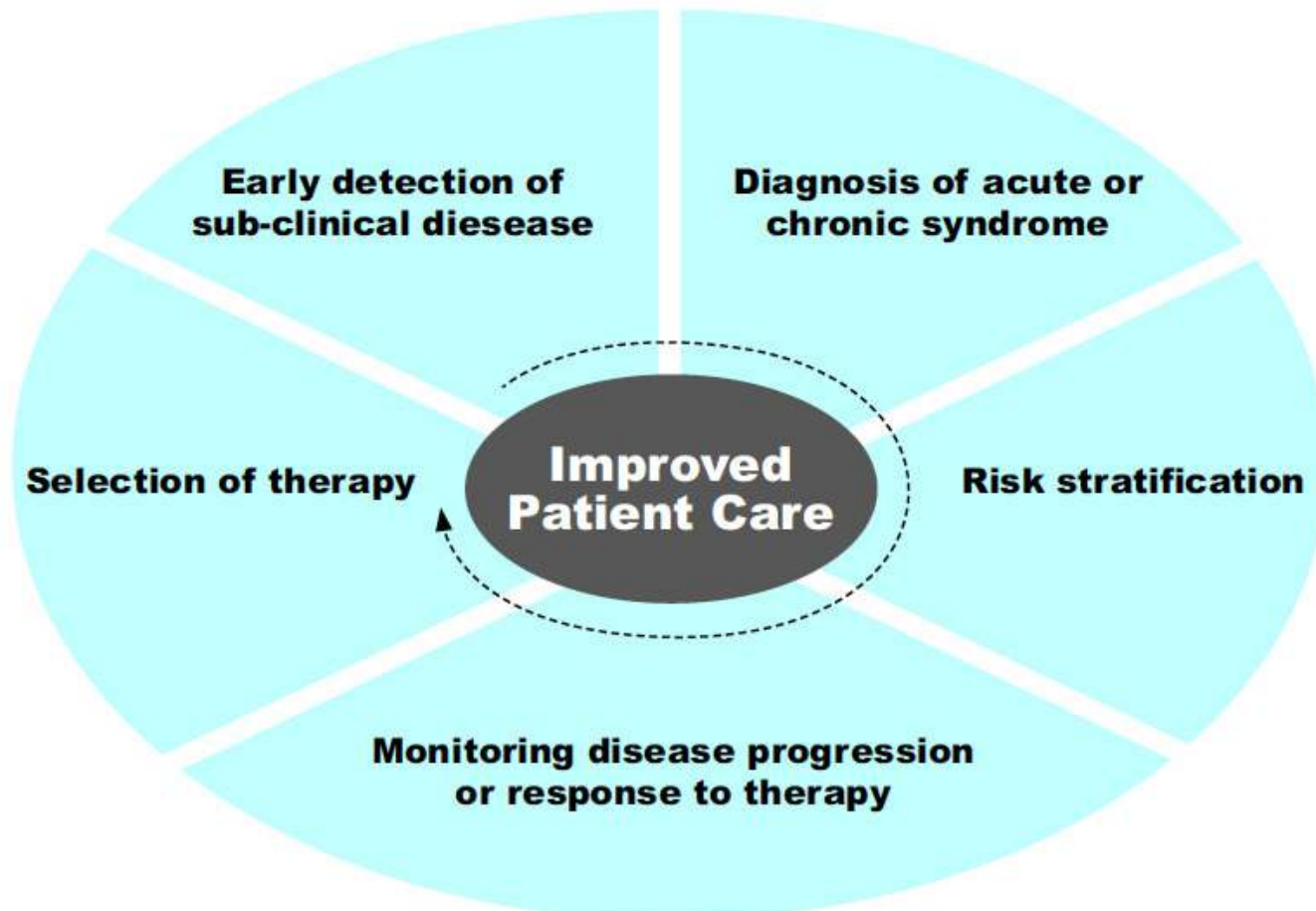

Figure 1. Clinical applications of cardiovascular biomarkers (Adapted with permission from Marrow DA, et al. American Heart Association 2007). 
The clinical translation of biomarkers in the assessment of coronary atherosclerosis is affected by the complex nature of the disease with multiple cellular and humoral factors, as well as often clinically silent progression, until reaching critical ischemic or vulnerable burden, leading to myocardial damage (27).

After the discovery and verification of the candidate proteins, robust immunoassays must be developed and optimizedtoevaluatetheirpotentialclinicalutility.Individual sandwich-based immunoassays using either monoclonal or polyclonal antibodies and nonisotopic labeled antibodies (e.g., alkaline phosphatase, fluorescein, and ruthenium) are used in this process. Although multiplexing technology is designed to simultaneously evaluate several putative biomarkers, at present the optimization of multiple protein assays is seldom achieved.

The analytical evaluation comprises several measures including trueness, accuracy, repeatability, and reproducibility, as well as a determination of linearity and limits of detection and quantification. Specific protocols for the assessment of these parameters are available to ensure a proper analytical performance evaluation of the new method (29-32). Furthermore, the frequency distribution of the candidate protein must be examined in healthy individuals to establish reference intervals to which patient results will be compared $(33,34)$. Evaluation of the candidate biomarker in control populations will determine whether the distribution of the protein is gaussian or skewed, and whether significant differences in values exist among different age, sex, or racial subgroups. Such information is essential in determining how the reference intervals will be established.

Once the clinical usefulness of a novel marker has been demonstrated, in vitro diagnostics (IVD) companies will decide whether to pursue it commercially. Technical, medical, financial, and legal considerations will also influence this decision (35). Markers used to predict future patient outcomes, which should not be confused with markers used as surrogate outcomes. The latter use of markers requires different criteria, as recently outlined $(36,37)$. Any marker used as a surrogate marker must have a clear and unambiguous association with subsequent patient outcomes in terms of biological or pathological processes or response to treatment.

Briefly, the process of biomarker development begins with the identification of target biomarkers with the use of standardized technology platforms, followed by validation of the assays $(39,40)$, statistical evaluation of biomarker distributions in reference samples and in those with disease, and assessment of the correlation between biomarker levels (or expression patterns of biomarkers) and clinical measurements that define disease status (41).
Novel Biomarkers for

\section{Cardiovascular Risk Assesement}

CVD accounts for nearly $50 \%$ of all deaths in developed countries. By 2020, heart disease and stroke are projected to become the leading cause of death and disability worldwide, with the number of fatalities set to increase to more than 20 million a year. By 2030 , this figure is set to increase to 23.6 million a year (41).

Currently, the only way to determine the risk for atherosclerotic pathological events is to perform annual estimates of the overall risk of CVD over 10 years. This is accomplished using traditional risk factors, such as age, sex, cholesterol level, diabetes or hypertension, in predetermined scoring models, such as the Framingham's model or the European Systematic Coronary Risk Evaluation (SCORE) model. Typically, this screening is routine from the age of 40 years in men and 50 years in women.

However, up to $50 \%$ of patients with CVD do not have high cholesterol or other traditional risk factors and, thus, are not recognized as being at risk (42). This means that approximately $30 \%$ of heart attacks are never predicted. Among these, many patients had previously been considered as being at medium risk, so were never prescribed treatment.

The ability to better predict the risk of cardiovascular events is one of the most important steps in reducing CVD and mortality. Most crucial to this is the ability to assess the risk of healthy individuals and detect atherosclerosis early - the largest target population for new biomarkers. Therefore, there is a strong need in the cardiovascular field for novel diagnostic tools that could help physicians to determine who is the most crucial to treat and to adapt their treatment strategy accordingly. Atherosclerosis is a chronic, complex and multifactorial disease. The consensus view among clinicians tends to be that a multimarker test could bring better detection of the vulnerable plaque than a single marker alone (43).

The multinational MONICA, Risk, Genetics, Archiving, and Monograph (MORGAM) (http://www. ktl.fi/morgam) project was initially established to develop cardiovascular risk scores based on classic risk factors and to determine whether genetic variability or biomarker assessment could improve on them. An overall summary of the project's objectives and detailed descriptions of the cohorts have been published elsewhere $(15,16)$. 


\section{Biomarkers in the MORGAM-Cohorts}

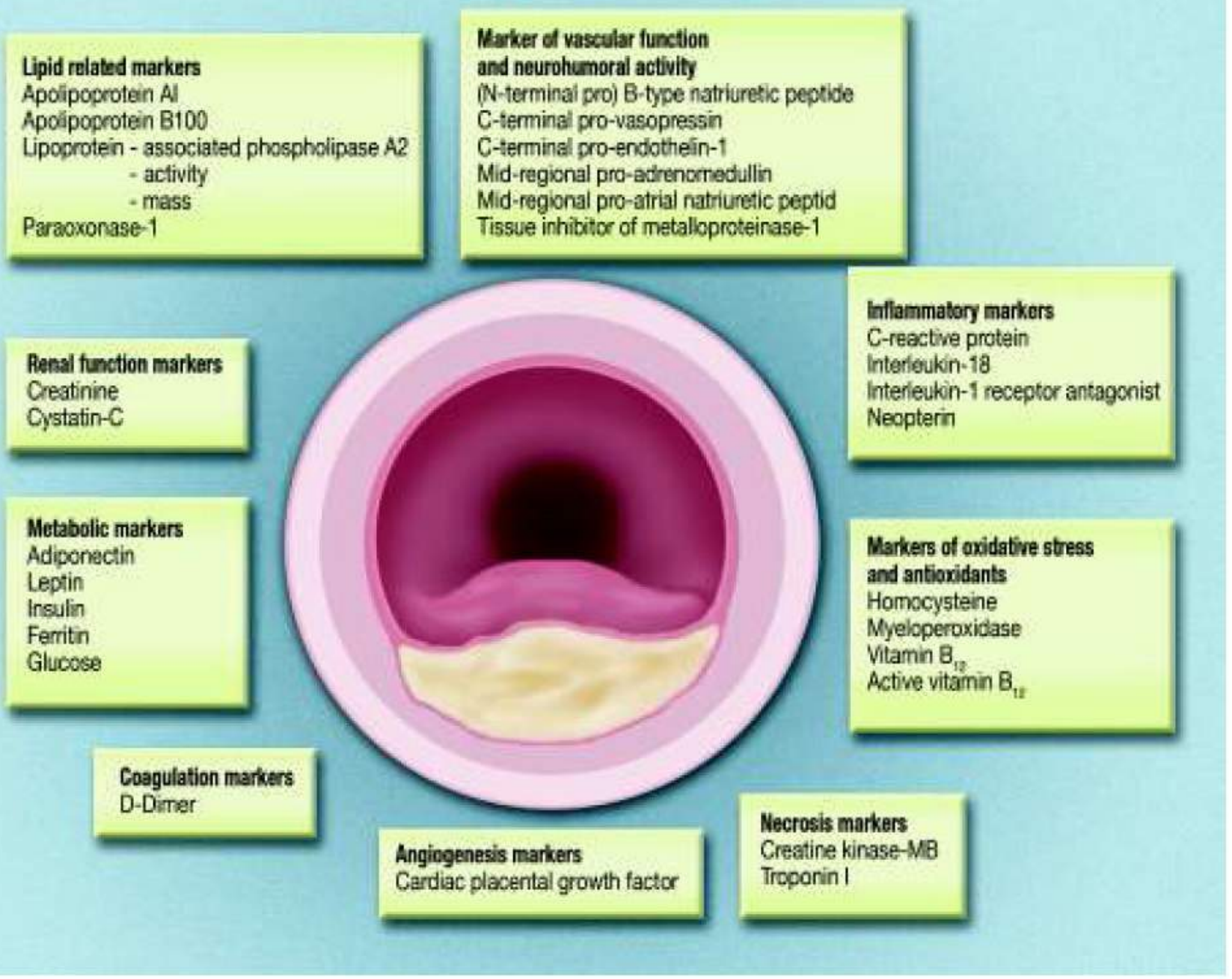

Figure 2. Biomarkers determined in the MORGAM cohorts (Adapted with permission from Blakenberg S, et al. American Heart Association 2010).

MORGAM Biomarker Project conclude that the addition of NT-proBNP, C-reactive protein, and troponin I to an established risk model improves 10-year risk estimation for nonfatal and fatal cardiovascular events in middle-aged European populations (46).

Low Density Lipoprotein (LDL) and High Density Lipoprotein (HDL) are well-established independent risk factors for cardiovascular disease (47). Several clinical trials have shown that lipid-lowering drugs aimed at LDL cholesterol (LDL-C) 8 reduce cardiovascular events by $30 \%-45 \%(48,49)$. The large residual risk in treated individuals may be partially explained by low HDL-C (50), but recent reports have suggested that increased HDL-C does not always protect against cardiovascular disease (51) and can sometimes be associated with increased coronary events (52).
Although epidemiologic studies have shown that low HDL-C is a negative risk factor, raising HDL-C pharmacologically has not been definitively established to protect against ischemic heart disease (IHD) $(51,52)$. This was especially evident from the recent study of the cholesteryl ester transfer protein (CETP)-inhibitor torcetrapib, which increased HDL-C concentrations but did not reduce cardiovascular events (52). A possible explanation for these contradictory findings may be that HDL becomes "dysfunctional" and may lose some of its antiatherogenic properties (53-55).

IHD was associated with high pre- $\beta 1$ HDL concentrations and low LCAT levels, yielding correct classification in more than $90 \%$ of the IHD cases for which both were measured, thus making pre- $\beta 1 \mathrm{HDL}$ concentration and LCAT activity level potentially useful 
diagnostic markers for cardiovascular disease (56).

Given the complexity of HDL metabolism and composition, it is perhaps not surprising that no single feature of HDL is sufficient to fully capture all of its antiatherogenic properties. We hope that in the future, tests for HDL biomarkers such as pre- $\beta 1 \mathrm{HDL}$ and LCAT will increase our ability to predict IHD risk and lead to the development of new and better drugs that modulate HDL-C concentrations (56).

A central tenet of atherosclerosis has been the concept that LDL undergoes modification into oxidized LDL (oxLDL) in tissues like the arterial wall. Uptake of oxLDL by macrophages and other vascular cells incites a cascade of events that promote inflammation, atherosclerosis, and eventually plaque rupture. A major advance in this area came with the identification of the lectin-like oxidized LDL receptor $1(\mathrm{LOX}-1)$ that, upon activation by ox-LDL binding, induces multiple proatherosclerotic responses in endothelial cells (ECs) as well as smooth muscle cells and macrophages (57).

Given the connections between LOX-1 pathways and atherosclerosis, Inoue et al. (58) reasoned that more focused measurements of LOX-1 and its activity might predict future cardiovascular events. LOX-1 can be released from the endothelial cell surface, generating soluble LOX-1 (sLOX-1). A plausible assumption is that sLOX-1 levels correlate with endothelial LOX-1 levels. Activation of LOX-1 in humans can be evaluated by use of the LOX index, obtained by multiplying the circulating concentration of LOX-1 ligands containing apolipoprotein $\mathrm{B}$ (LAB) times that of the soluble form of LOX-1 (sLOX-1) $[$ LOX index $=\mathrm{LAB} \times$ sLOX-1] (58). Higher LOX index values were associated with an increased risk of CHD. Low LOX index values may be protective against ischemic stroke (58).

These data also serve as a model to think about where advances in science and the need for better predictive tools might take us. No doubt additional players that either protect against or promote atherosclerosis, including that which occurs in distinct vascular beds, will continue to be identified - the vector of basic biomedical research (57).

Genetic studies have succeeded in demonstrating that Lp (a) is not just a biomarker of increased risk of IHD but a causal factor. In addition, the recent large meta -analysis of individual data from 126,634 participants from 36 prospective studies demonstrates the robustness of the association between elevated levels of lipoprotein(a) and increased risk of cardiovascular disease. Together, this warrants that lipoprotein(a) should be taken much more seriously in the future, for cardiovascular risk examination and potentially as a target for drug therapy. Therefore, it is our hope that renewed interest in lipoprotein(a) may be spurred. Despite numerous past studies there are still unknowns, such as the exact mechanism of how lipoprotein(a) causes MI, is it primarily via increased atherosclerosis or increased thrombosis or a combination of both?

The soluble Phospholipase A2 (sPLA2) constitutes a family of nine enzymes in humans that generate fatty acids and lysophospholipids, and trigger a variety of proinflammatory actions. It is now well accepted that SPLA2 plays a crucial role in the formation and destabilization of atherosclerotic plaque and contributes to lipoprotein retention, foam cell formation and inflammation in a developing lesion. Furthermore, the potential clinical benefit of SPLA2 inhibitors in the treatment of CVDs has already been explored in several Phase II trials, and these molecules will enter Phase III in the coming months. Last, but not least, sPLA2 activity recently emerged as a very promising biomarker for cardiovascular risk (43).

\section{Novel Biomarkers for ACS}

Chest discomfort is the leading symptom in patients with coronary artery disease as well as the leading cause of presentation to the emergency department (63). The initial evaluation is based on the patient's clinical history, changes in the ECG and necrosis biomarkers. Historically, glutamate oxaloacetate transaminase was found to be elevated in the blood of patients having an acute myocardial infarction (64). Since then, other biomarkers, such as creatinin kinase, myoglobin and troponin, have facilitated early and accurate detection of myocardial damage and necrosis. Among them, troponin bears the highest diagnostic accuracy and is the cornerstone of the contemporary management of acute coronary syndrome (ACS) (65). Given that troponin, as a marker of myocardial damage, detects terminal events in the cascade of ACS, there is a need to search for biomarkers that are able to identify patients at high risk, allowing rapid, bedside stratification.

\section{BIOMARKERS FOR OXIDATIVE STRESS AND INFLAMMATION IN ATHEROSCLEROSIS}

Atherosclerosis has become increasingly recognized as a pathological state, characterized by the accumulation of oxidative stress and inflammation in association with lipids in the artery wall (66-68). These processes have been implicated at all stages of the disease, from the very early appearance of endothelial dysfunction, through the 
propagation and rupture of atherosclerotic plaque and, ultimately, tissue injury, in the settings of both ischemia and reperfusion. Accordingly, there has been considerable interest in the monitoring of these pathways as potential biomarkers for CVD (69).

Central to the atherosclerotic process is the role of oxidized forms of low-density lipoprotein (LDL) (70,71). Following its entry and trapping within the artery wall, LDL particles are rapidly oxidized by these systems. Oxidized LDL (oxLDL) is avidly taken up by macrophages forming foam cells, the cellular hallmark of atherosclerotic plaque. Each of these pro-oxidant pathways have been demonstrated to be regulated by multiple risk factors, including hypertension, dyslipidemia and impaired glucose tolerance.

Inflammatory cells have been implicated at every stage of the disease process (68). The stage of endothelial dysfunction that precedes any pathological change within the vessel wall is characterized by upregulation and expression of a number of proinflammatory factors on the endothelial cell surface $(72,72)$. Pathological studies have observed that the earliest atherosclerotic lesion is often a pure inflammatory lesion, consisting only of monocytederived macrophages and $\mathrm{T}$ lymphocytes (74). It is only after they are recruited into the artery wall that monocytes undergo a morphological change to become macrophages and express scavenger receptors that bind modified lipoproteins $(68,71)$. These macrophages subsequently become lipid-laden foam cells by engulfing modified lipoproteins.

Recent work has identified specific inflammatory pathways, regulated by myeloperoxidase (MPO) and various members of the phospholipase family that mediate a range of pathological events within the artery wall $(75,76)$. The elucidation of the factors involved in the promotion of oxidative and inflammatory pathways in the artery wall provides an important opportunity to develop new systemic biomarkers for potential clinical use.

\section{I.1. Biomarkers for oxidative stress}

Oxidative stress biomarkers can be broadly classified in to two major categories: biomolecules damaged by ROS, and antioxidant enzymes and molecules. The first category includes molecules that are generated in a reaction with ROS.

In the process of atherosclerosis, clinically applicable biomarkers include 8 hydroxy-2' deoxyguanosine (8 OHdG; a marker of oxidative DNA damage) (77), lipid peroxidation represented by isoprostanes (78), malondialdehyde (MDA) and thiobarbituric acid reactive substance (markers of lipid peroxidation), carboxymethyl-lysine and pentosidine (markers of glyco-oxidation), and nitrotyrosine (marker of nitrooxidation) $(79,80)$.

The second category consists of antioxidant enzymes and molecules that are associated with ROS metabolism. In the process of atherosclerosis, clinically applicable biomarkers include superoxide dismutase, glutamine peroxidase, catalase, heme oxygenase, thioredoxin and paraoxonase (80-82). Plasma total antioxidant status is also measured as a factor to show the general antioxidant status (83).

\section{a) Asymmetric dimethylarginine}

Excess ROS has been demonstrated to decrease the endothelial bioavailability of nitric oxide (NO) and promote endothelial dysfunction. Assymetric dimethylarginine (ADMA) is an endogenous inhibitor of NOS, which results in reduced NO synthesis $(84,85)$. ADMA represents an important link between ROS and endothelial dysfunction via the reduced bioavailability of NO. ADMA decouples NOS from 1 arginine and, therefore, reduces NOS-derived NO production. There is also some evidence that ADMA may even cause NOS uncoupling, thereby switching NOS from NO to a superoxide-producing enzyme.

\section{b) Oxidized $L D L$ (ox- $L D L$ )}

Low-density lipoprotein is an important target of oxidation. oxLDL reflects a variety of modifications of the lipid and protein components of LDL that occur when oxygen free radicals react with polyunsaturated fatty acids and induce lipid peroxidation. oxLDL is considered to be a key step in the pathogenesis of atherosclerosis $(70,71)$. oxLDL, with its many oxidatively modified lipids and degradation products, contributes to the pathophysiology of both the initiation and progression of atherosclerosis. oxLDL concentrations are strongly correlated with plasma LDL concentrations and, thus, the latter is a key factor in determining absolute plasma oxLDL concentration.

\section{I.2. Biomarkers for inflammation}

A number of proinflammatory factors have been proven to induce the initiation and progression of atherosclerosis. Recent prospective studies have consistently demonstrated that the usefulness of these molecular proinflammatory biomarkers to predict future cardiovascular events not only in apparently healthy subjects, but also in patients with acute coronary 
syndrome (86-90). Measurements of these biomarkers carry important prognostic information, independent of traditional risk factors

\section{a) $C$-reactive protein $(C R P)$}

CRP is predominantly synthesized in hepatocytes as an acute-phase reactant and is transcriptionally driven by IL 6 , with synergistic enhancement by IL 1. It is also suggested that CRP is produced locally in vascular smooth muscle cells and macrophages in atherosclerotic lesions (68). CRP has initially been considered as a reactant of inflammation, however, recent evidence suggests that CRP itself has direct proinflammatory effects (91-93). Several mechanisms of CRP that may contribute to the initiation and progression of atherosclerosis have been reported, including promoting endothelial dysfunction, activation of circulating monocytes, induction of prothrombotic state and increased uptake of oxLDL (94).

\section{b) Myeloperoxidase (MPO)}

Myeloperoxidase, one of the enzymes of the innate immune system, is considered to be a bactericidal agent (76). MPO are derived from neutrophils and monocytes, and now have been identified in human plaques. A number of studies demonstrated the importance of MPO in CVD $(76,96)$. In the system of LDL oxidation, several studies reported that MPO-generated reactive nitrogen species mediate LDL protein nitration, initiate LDL lipid peroxidation, and convert the lipoprotein into a form that promotes cholesterol deposition in macrophages and foam-cell formation (97). In addition to its role in foam-cell formation, MPO has been identified as a catalytic sink for NO (98). More recently, it has been demonstrated that MPO is a critical factor involved in the generation of impaired protective biological properties of HDL(99). Dysfunctional HDL particles lack atheroprotective properties and promote proinflammatory effects.

\section{c) Lipoprotein-associated phospholipase A2}

(Lp-PLA2)

Lp-PLA2 is an enzyme, a member of the phospholipase A2 superfamily and is produced by monocytes, T lymphocytes and mast cells. LpPLA2 is formed in the hydrolysis of oxLDL and results in a formation of lysophosphatidylcholine, a proatherogenic and inflammatory mediator (100). In plasma, approximately $80 \%$ of Lp-PLA2 is bound to LDL, and the remaining $20 \%$ is linked to $\mathrm{HDL}$ and very-low-density lipoprotein. On the other hand, several studies support an anti-inflammatory function of Lp-PLA2 $(99,100)$. The protein has been demonstrated to play a role in the hydrolysis of the platelet-activating factor and manifests a possible antiatherogenic effect when high levels of Lp-PLA2 are associated with HDL in mice (101). However, at least in the clinical studies, Lp-PLA2 has demonstrated an association with the risk of CVD (102).

\section{d) Soluble CD40 ligand ( $s C D 40 L$ )}

The potent immune mediator CD40 and its counterpart CD40 ligand (CD40L) participate in numerous inflammatory pathways that contribute to multiple pathophysiological processes (103, 104). CD40/CD40L have been demonstrated to be coexpressed by all major cells implicated in atherosclerosis, including activated $\mathrm{T}$ lymphocytes, endothelial cells, smooth muscle cells and monocyte/ macrophages. Both the receptor and the ligand are functional and $\mathrm{CD} 40 / \mathrm{CD} 40 \mathrm{~L}$ interactions enhance the expression of various proatherogenic molecules, such as adhesion molecules, chemokines, cytokines, growth-factors and matrix metalloproteases. Circulating soluble CD40L has been suggested to activate endothelial cells and CD40 expressed in other cells, constitutive for the atherosclerotic plaque, and induce a proinflammatory cascade in the vessel wall.

\section{BIOMARKERS FOR PLAQUE DESTABILIZATION AND RUPTURE}

Biomarkers of vulnerable plaque can potentially provide useful information for the management of patients with coronary artery disease. Ideally, they should reflect a window in the early stage of vulnerable plaque or plaque potentially prone to rupture. The identification of such a window is of immense clinical importance.

Therefore, it is reasonable to hypothesize that biomarkers reflecting reversible ischemia will identify patients with high cardiovascular risk and can be tested as surrogate markers of vulnerable plaque. Here, we described six biomarkers that have been linked to myocardial ischemia. Until now, these biomarkers of ischemia are relevant in order to exclude ischemic heart disease (high negative predictive value) but still lack specificity (105).

a) Ischemia-modified albumin (IMA) IMA is one of the most thoroughly studied 


\section{Table 1. Oxidative stress and inflammatory biomarkers in human studies reflecting cardiovascular risk (adapted with permission from Uno K et al. Future Science Group 2010).}

\begin{tabular}{lll}
\hline Condition & Increase & Decrease \\
\hline $\begin{array}{l}\text { Atherosclerotic risk factor } \\
\text { Hypertension }\end{array}$ & $\begin{array}{l}\text { 8-OHdG, oxLDL, MDA, lipid peroxides/nitric oxide } \\
\text { Diabetes Mellitus }\end{array}$ & GSH, SOD \\
$\begin{array}{l}\text { isoprostanes, nitrotyrosine, carboxmethyl-lysine } \\
\text { Metabolic Syndrome, obesity }\end{array}$ & isoprostanes, 8-OHdG & GSH \\
$\begin{array}{l}\text { Preclinical atherosclerosis } \\
\text { Predict future atherosclerotic disease }\end{array}$ & oxLDL, IL-6, MPO, Lp-PLA2, CRP & adiponectin \\
$\begin{array}{l}\text { Endothelial dysfunction } \\
\text { Clinical atherosclerosis }\end{array}$ & NADPH oxidase, isoprostanes, ADMA, sICAM-1 & TAOS \\
Symmetrical atherosclerosis & & \\
Coronary artery disease & ADMA & \\
Acute coronary syndrome & oxLDL, MCP-1, MPO & \\
& oxLDL, sCD40L & \\
\hline
\end{tabular}

8-OHdG: 8-hidroxy-2'-deoxyguanosine; ADMA: Asymmetric dimethylarginine; CIMT: Carotid intima-media thickness; CRP: C reactive protein; GSH: Reduced glutathione; Lp PLA2: Lipoprotein-associated phospholipase A2; MCP: Monocyte chemoattractant protein; MDA: Malondialdehyde; MPO: Myeloperoxidase; oxLDL: Oxidized low-denstiy lipoprotein; PAl: Plasminogen activator inhibitor; sCD40L: Soluble CD40 ligand; sICAM: Soluble ICAM; SOD: Superoxide dismutase; TAOS: Total antioxidant status; TBARS: Thiobarbituric acid reactive substance.

biomarkers approved by the US FDA for clinical use. It has been demonstrated that the capacity of albumin to bind transition metals (specifically cobalt, copper and nickel) in the setting of myocardial ischemia was diminished (106,107). During ischemia, the $\mathrm{N}$ terminus of albumin is modified, possibly owing to hypoxia, acidosis, free-radical injury and energy-dependent membrane disruption, therefore, decreasing its binding capacity for metals $(108,109)$. These modifications were used to develop an albumin cobalt binding (ACB) test that measures the residual unbound cobalt fraction. This unbound cobalt fraction is used to bind a chromogen, which, in turn, can be measured photometrically (107).

The ACB test has been demonstrated to correlate with myocardial ischemia. Initial work demonstrated that changes in IMA can occur as early as $6-10 \mathrm{~min}$ after myocardial ischemia starts and this remains positive up to $6 \mathrm{~h}$ later $(110,111)$. Thus, the $\mathrm{ACB}$ test detects ischemia before the development of necrosis and before an elevation of the conventional markers of necrosis (creatine kinase MB and troponin).

b) Unbound free fatty acid (FFA)

Total serum FFA levels provide an important measure of the physiologic state. Owing to the fact that large quantities of FFA are required to meet energy needs and since long-chain FFAs are highly insoluble in the aqueous phase, the major portion of FFA in the blood is carried in association with albumin. A small part of the total FFA within the blood, however, dissociates from the albumin. These molecules, the unbound FFA (FFAu), are in true aqueous solution as monomers of FFAu (112).

FFAu has been assessed in the setting of transient ischemia created by balloon inflation during PCI $(113,114)$. FFAu demonstrated a rapid increase after balloon inflation. There were no significant associations between the peak FFAu level and total balloon inflation duration, ECG changes, prolonged angina, procedural complications, left ventricular function or number of lesions treated (113).

\section{c) Choline}

Choline is an essential component of phospholipids, plasma lipoproteins and cell membranes, and is crucial for the formation of acetylcholine. The hydrolysis of phosphatidylcholine by phospholipase D generates choline and phosphatidic acid (115). Whole-blood choline has been studied in the context 
of ACS and has been demonstrated to be predictive of cardiac death during 30 days following an ACS in patients with negative troponin. In addition to whole-blood choline, serum choline has been studied in the context of ACS with troponin-negative patients, where it was shown to be predictive of cardiovascular events in conjunction with F2 isoprostane (116).

\section{d) Brain Natriuretic Peptide \& N-Terminal proBNP (BNP \& NT-proBNP)}

BNP is released upon ventricular stress together with its inert cometabolite NT proBNP (117). In the context of ischemia, it is not completely clear which stimulus launches the release of BNP. Wall stress is probably the main trigger but hypoxia itself could also be an independent trigger $(118,119)$. Although numerous studies have demonstrated a predictive value of natriuretic peptide levels in the context of myocardial infarction (120), ACS (121) and stable coronary artery disease $(122,123)$, few have assessed the value of BNP (NT proBNP) as a marker of ischemia. Bibbins-Domingo et al., have demonstrated that elevated levels of BNP were associated with inducible ischemia and, accordingly, with an increased risk of coronary events (124).

\section{e) Cystatin C}

A recently published study demonstrated an association between cardiac ischemia and cystatin $\mathrm{C}(125)$. The association was statistically significant among patients without a history of coronary artery bypass and those who were not treated with $b$ blockers or statins. After adjustment for baseline demographics, comorbidities, medications, creatinine clearance, cardiac function and C reactive protein, the highest cystatin $\mathrm{C}$ quartile predicted inducible ischemia. Although these data are interesting, the causal pathway between cystatin $\mathrm{C}$ and ischemia is currently an unresolved issue.

\section{f) High - sensitivity troponin}

Recently, a highly sensitive troponin $\mathrm{T}$ assay that can detect levels as low as $0.001 \mu \mathrm{g} / 1$-ten-times lower than the conventional available test - has been developed. The mechanisms responsible for the release of very low levels of cardiac troponin $\mathrm{T}$ in patients with stable coronary artery disease could include transient ischemic episodes. Recently, Sabatine et al., using the ultrasensitive troponin T assay, demonstrated a quantifiable rise in troponin $\mathrm{T}$ levels in patients undergoing stress testing, with the amount of rise being proportional to severity of

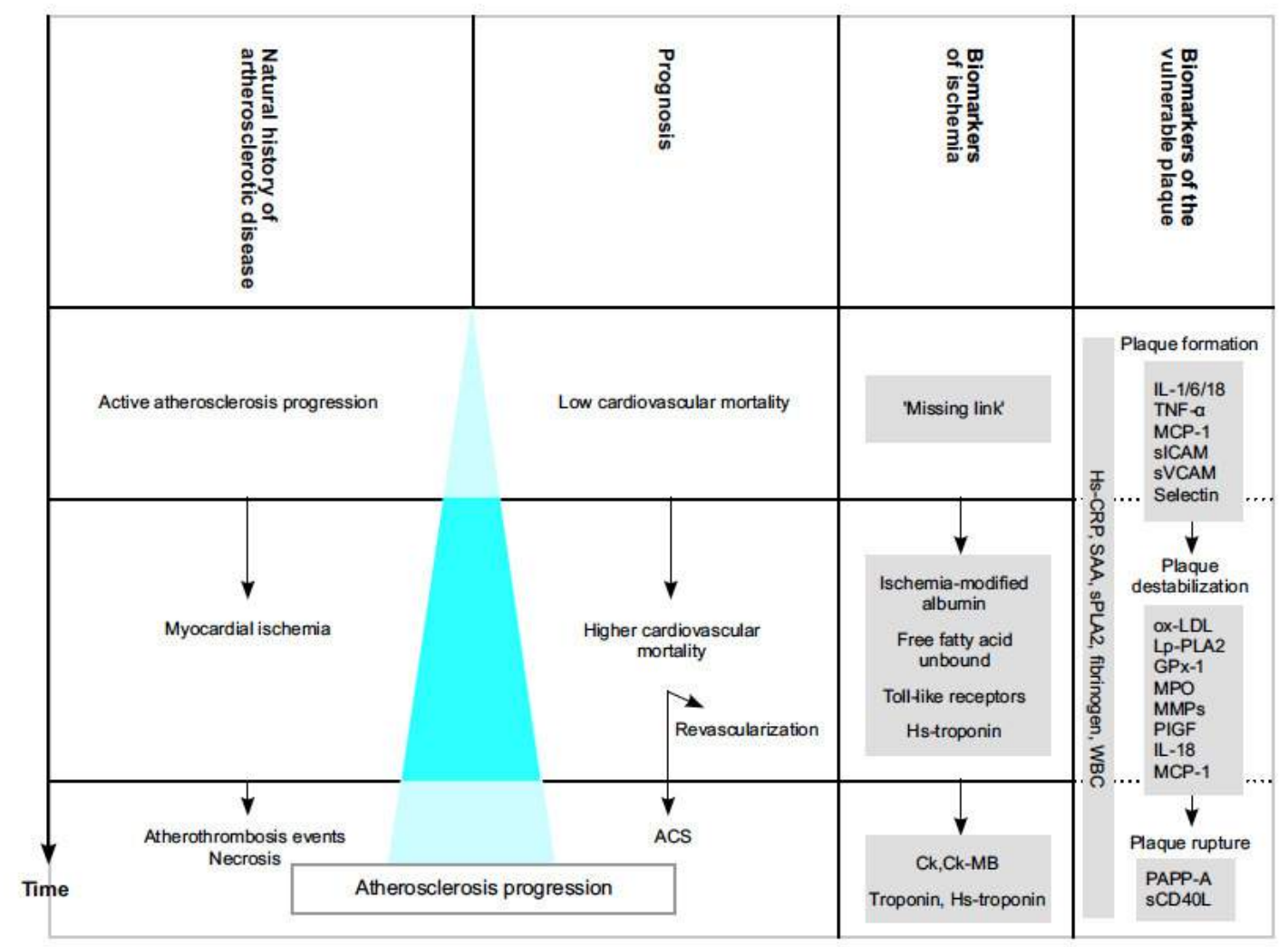

Figure 3. Atherosclerotic disease develops over years, beginning with fatty streaks and ending in plaque rupture (Adapted with permission from Muller O, Future Science Group 2010). 
ischemia on perfusion imaging (126) Furthermore, the authors identified a rise of troponin $\mathrm{T}$ levels to over $0.0013 \mathrm{ng} / \mathrm{ml}$ as a strong predictor of inducible ischemia, with an odds ratio of 3.54 with $95 \% \mathrm{CI}$ of $1.42-8.80$.

\section{BIOMARKERS FOR ISCHEMIA AND NECROSIS}

The diagnosis of acute myocardial infarction currently rests on the measurement of troponin, a biomarker of myocardial necrosis. Unfortunately, the current generation troponin assays detect troponin only 6-9 h after symptom onset. This can lead to a delay in diagnosis and also excessive resource utilization when triaging patients who, ultimately, have noncardiac causes of acute chest pain. For these reasons, there has been extensive research interest in biomarkers that can detect and rule out myocardial infarction early after symptom onset. These include markers of myocardial injury, such as myoglobin, hearttype fatty acid binding protein, glycogen phosphorylase $\mathrm{BB}$; hemostatic markers, such as d-dimer; and finally, inflammatory markers, such as matrix metalloproteinase 9 . Recently, highly sensitive troponin assays have reported an early sensitivity for myocardial infarction of greater than $95 \%$, although at a cost of reduced specificity. The optimal strategy with which to use these novel biomarkers and highly sensitive troponins has yet to be determined, and interpretation of their results in light of thorough clinical assessment remains essential (127).

\section{a) Heart-type fatty acid binding protein (H-FABP)} HFABP is a small (14-15 kDa) cytosolic protein found abundantly in cardiac tissue and to a much lesser extent in the brain, liver and intestine. Several studies have examined the role of HFABP in diagnosing MI. An early study demonstrated that the diagnostic sensitivity of HFABP was superior to that of myoglobin and creatine kinase $\mathrm{MB}$, and that in patients presenting between 3 and $4.5 \mathrm{~h}$ after symptom onset, sensitivity could be as high as $94 \%$ (128). Further investigations found similar results in larger populations (129) and in patients with undifferentiated chest pain (130). The most recent prospective study to assess HFABP's diagnostic utility reported significantly better sensitivity of HFABP when compared with troponin $\mathrm{T}$ in patients presenting less than $4 \mathrm{~h}$ after the onset of symptoms (131).

\section{b) Matrix metalloproteinases 9 (MMP 9)}

MMP 9 are a family of zinc-dependent endopeptidases with the functional ability to breakdown components of the extracellular matrix (132). The role of MMP 9 in atherosclerosis and plaque rupture is supported by several investigations, such as the observations that within coronary atherectomy specimens, MMP 9 levels were $70 \%$ higher in patients with unstable versus stable symptoms (133) and that unstable plaques stain more strongly for MMP 9 than those with stable symptoms (134).

\section{c) Soluble CD40 ligand (sCD4OL)}

The CD40 ligand is expressed on a wide variety of cells, including leukocytes and activated platelets $(135,136)$. It is recognized to play a vital role in the inflammatory progression of atherosclerosis $(137,138)$ as well as being part of a signaling pathway involved in the initiation of plaque rupture (139). Once activated, platelets shed a functionally enabled soluble form of the CD40 ligand (sCD40L) that enables relatively easy sampling from the peripheral blood (140). In a cohort of over 1000 patients with confirmed ACS, sCD40L was an independent predictor of 30 day death or MI, and stratified a high-risk group of patients who may benefit from glycoprotein IIB/IIIa inhibition (141).

\section{d) Pregnancy-associated plasma protein A (PAPP-A)} PAPP-A in relation to ACS has been extensively investigated. PAPP-A is a member of the MMP family (142), and is frequently measured in the serum of pregnant women to help stratify risk for the presence of fetal trisomy (143). Evidence of its potential role in ACS was first reported by BayesGenis's group in 2001. Initial autopsy derived 'unstable plaques' compared with 'stable' plaques exhibited much stronger staining for PAPP-A. This led the group to undertake subsequent measurements of PAPP-A levels in a small number of patients with ACS, stable angina and normal controls, confirming the association between peripheral PAPP-A levels and ACS (144). Further investigation in a cohort of 644 patients attending an emergency department with chest pain, again demonstrated a significant association of elevated PAPP-A levels with ACS and, importantly, elevated levels were predictive of death or MI independent of troponin and SCD40L (145).

\section{e) High Sensitive Troponin Assay}

Very recently, two independent investigators have published interesting studies involving highly 
sensitive troponin assays $(146,147)$. These assays have a lower limit of detection that is below the 99th centile upperreferencelimitfor the normal population (148-150). The sensitivity of an admission sample alone for the diagnosis of MI was as high as $95 \%$. When comparing the AUC-ROC curve for highly sensitive and standard troponin assays, the superior discriminatory power of the highly sensitive assays was evident from the admission sample in contrast to the requirement for delayed sampling with the standard assay. Furthermore, the negative predictive value of all four assays, investigated at the 99th percentile, was between 95 and $97 \%$, utilizing only an admission sample (147). The value of these impressive early sensitivity results may be offset by a significant reduction in specificity (151-153).

\section{f) $Y K L 40$}

YKL 40 is a glycoprotein secreted in vitro by human cells such as activated macrophages and neutrophils in different tissues with inflammation and increased remodeling of the extracellular matrix (ECM), by arthritic or injured chondrocytes, by fibroblastlike synovial cells and by vascular smooth muscle cells (VSMCs). In vivo YKL 40 has been found elevated in patients with diseases characterized by inflammation, increased extracellular remodeling and ongoing fibrosis (154).

YKL 40 is named after its three $\mathrm{N}$-terminal amino acids and its molecular mass of $40 \mathrm{kDa}$ (155). YKL 40 is also known as human cartilage glycoprotein-39 (HC gp39) (156), breast regressing protein 39 (brp39) (157), 38-kDa heparin-binding glycoprotein (gp38k) (158), chitinase-3-like-1 (CHI3L1) (159), chondrex (160) and 40-kDa mammary gland protein (MGP-40) (161).

YKL 40 is closely related to both the early and late phases in the development of atherosclerosis. One of the key elements in the early development of atherosclerosis is the maturation of monocytes into macrophages in the arterial intima layer. Subsequent to this the macrophages take up lipids and replicate. The lipid-rich macrophages, known as foam cells, secrete inflammatory mediators that stimulate smooth muscle cell migration and proliferation and participate in plaque development and rupture as well as thrombosis $(162,163)$.

YKL 40 induces the maturation of monocytes to macrophages and is secreted by macrophages during late stages of differentiation and by activated macrophages (159,164-167). Macrophages in atherosclerotic plaques express YKL 40 mRNA, particularly macrophages that had infiltrated deeper in the lesion, and the highest expression of YKL 40 is found in macrophages in the early lesion of atherosclerosis (168). The last part is particularly interesting because it suggests that YKL 40 could be used as a biomarker for atherosclerosis at very early stages of the disease. Several studies of patients with AMI and/or stable CAD have demonstrated elevated levels of YKL 40 compared with healthy controls (169-174).

Two large studies have both demonstrated that YKL 40 can be used as an independent predictor for both overall and $\mathrm{CV}$ mortality in both individuals with or without CVD $(172,174)$. These findings support the hypothesis, that YKL 40 is closely related to both the early and late phases in the development of atherosclerosis. It could be a measure of the inflammatory activity in coronary artery plaques and thereby an indicator of the risk of developing an acute coronary syndrome or death.

Results from these studies suggest that YKL 40 could be a new biomarker of acute and chronic inflammation in patients with stable CAD. Circulating YKL 40 may reflect the total burden of coronary atherosclerosis or identify a high-risk atherosclerosis phenotype with ongoing inflammation and atherosclerotic plaque formation.

The diagnosis of MI remains challenging. Despite the development of novel assays measuring necrosis, hemostasis and inflammation, not one single test can fully exclude or confirm the presence of ACS or MI. Recently, the combination of a marker of hemodynamic stress (copeptin) with fourthgeneration troponin (175) has shown promise; however, the potential of this strategy requires further prospective validation.

\section{Novel Biomarkers for Heart Failure}

Heart failure is associated with significant mortality, morbidity and economic cost (176). Over the past 30 years, our understanding of the pathophysiology of heart failure has advanced greatly. It is now recognized as a systemic syndrome characterized by maladaptive neurohormonal, metabolic and inflammatory processes. The recognition of these pathways has prompted the evaluation of some of their components as biomarkers in both chronic heart 
failure (CHF) and acutely decompensated heart failure (177).

Established biomarkers, such as B-type natriuretic peptides, have improved the diagnosis and prognostication of heart failure patients. However, morbidity and mortality rates remain high, and the development of further biomarkers may improve the management of these patients. Novel biomarkers in heart failure should add to contemporary diagnostic and prognostic acumen and be cost effective. Much work is required to ascertain which of these candidate biomarkers or their combinations have a place in contemporary clinical practice and, if so, how they will be best utilized.

\section{NEUROHORMONES}

Maladaptiveneurohormonalaugmentationisnowrecognized as a major contributor to the development and progression of CHF. As our understanding of CHF pathophysiology progresses, components of novel neurohormonal pathways with putative roles, both protective and deleterious, are similarly declaring themselves as candidate biomarkers (177).

\section{a) Human brain natriuretic peptide (BNP)}

Human brain natriuretic peptide (BNP) is an established biomarker in heart failure. It belongs to the category of cardiac-specific markers that are released by the heart in response to myocardial stress. The peptide is synthesized as a 134 amino acid peptide (pre-proBNP) that is subsequently processed to form a 108-amino acid peptide (proBNP). This proBNP is enzymatically cleaved by corin, a transmembrane serine protease produced in cardiomyocytes to form a 76-amino acid $\mathrm{N}$-terminal NT peptide (NT-proBNP) and a biologically active 32-amino acid C-terminal peptide (BNP), which are both released into the circulation. The biologically active BNP, the intact 108-amino acid proBNP and the remaining part of the prohormone NT-proBNP, all circulate in the plasma and can be measured by commercially available immunoassays. They bear diagnostic and prognostic relevance, can track the therapeutic response and testing is recommended in current guidelines (178-182).

In critically ill patients, BNP levels seem to be related to prognosis in several clinical situations, such as hypoxemic pulmonary failure (183), pulmonary embolism (184), myocardial infarction (185) or septic shock $(186,187)$.

The natriuretic peptides are the most widely studied of the heart failure biomarkers. They form a family of peptides possessing natriuretic, diuretic and vasodilatory properties that are endogenously upregulated in heart failure. Given their greater stability in plasma, the B-type natriuretic peptides (BNPs) are now widely recognized as the current 'biomarker benchmark' in both CHF and acutely decompensated heart failure. Their established role in the diagnosis, prognosis and, maybe less convincingly, guidance of therapy in CHF, has recently been comprehensively reviewed in many journal (188).

\section{b) Midregional pro - atrial natriuretic peptide}

The midregional segment of the pro-atrial natriuretic peptide molecule (MR-proANP) has been shown to be more stable in the plasma than either proANP or mature ANP and is emerging as a promising biomarker in this syndrome. Several small studies have demonstrated that this peptide can reliably diagnose heart failure in acutely breathless patients with a seemingly similar performance to BNP and amino-terminal BNP (NT-proBNP) (189), and also identifies asymptomatic left ventricular (LV) systolic dysfunction in patients with coronary artery disease with a performance comparable to NTproBNP (190).

This novel peptide provided independent prognostic information in 525 (191) and 797 (192) CHF patients, which, importantly, appears to be superior to the BNPs in both cases. Therefore, MRproANP holds considerable promise as a diagnostic and prognostic biomarker in both acute heart failure and $\mathrm{CHF}$.

\section{c) Midregional pro-adrenomedullin}

Adrenomedullin (ADM) is a complex 52-amino acid peptide that was initially isolated from human pheochromocytoma cells and is almost ubiquitously expressed throughout the human cardiovascular system (193). It has potent vasodilator and natriuretic properties, and both myocardial and plasma levels are raised in CHF, with plasma levels predicting mortality in CHF (194). Accurate assaying of plasma levels can be inaccurate as its half-life is short. However, an assay has been developed for the more stable midregional portion of the propeptide (195). One small observational study has suggested that plasma levels of midregional proADM are of moderate value in identifying LV systolic dysfunction in patients with coronary artery disease with a negative predictive value of $88 \%$ (196). 
In a large study of 923 postmyocardial infarction patients, plasma concentrations of midregional proADM were elevated and powerfully predictive of both mortality and progression to CHF following multivariable analysis (197). Circulating levels were also increased and predictive of mortality at 24 months in $786 \mathrm{CHF}$ patients, with greatest prognostic value in those with mild-moderate disease severity (198).

\section{d) C-terminal pro-arginine vasopressin (copeptin)}

Arginine vasopressin (AVP), or antidiuretic hormone, is synthesized in the supraoptic and paraventricular nuclei of the hypothalamus. It is a vasoconstrictor but its prime role is in the regulation of fluid homeostasis by promoting water reabsorption in the collecting ducts of the nephron (199). Plasma AVP concentrations have long been known to be elevated in CHF (200). An assay has recently been developed for the C-terminal fragment of proAVP, also known as copeptin (201). Copeptin is raised and independently predictive of adverse LV remodeling and mortality in patients following acute myocardial infarction (202-204). It also predicted 1-year mortality in 137 patients with acutely decompensated heart failure (205). Larger observational studies in CHF patients demonstrated similar prognostic properties, which appeared to provide superior information to BNP regarding mortality across the spectrum of disease severity (206,207).

\section{e) Chromogranin $\mathrm{A}(\mathrm{CgA})$}

$\mathrm{CgA}$ is a 439-aminoacid member of the granin family of neuropeptides that is ubiquitously distributed throughout the CNS, endocrine and neuroendocrine systems of vertebrates and nonvertebrates (208). $\mathrm{CgA}$ is also synthesized in the human myocardium (209) and is the precursor for a range of $\mathrm{N}$-terminal fragments with various vasoactive, metabolic and antimicrobial properties (210).

Both circulating (211) and myocardial levels (209) are raised in CHF, correlating with New York Heart Association (NYHA) class and predicting prognosis. $\mathrm{CgA}$ concentrations similarly predict prognosis in patients presenting with acutely decompensated heart failure (212).

\section{f) Apelin}

The peptide hormone apelin is also ubiquitously expressed throughout the cardiovascular system
(213) and is the ligand for the G-protein-coupled receptor known as APJ (214). Studies in animals have demonstrated antihypertensive (215-217), vasodilatory (218), diuretic (219-221) and potent inotropic effects in normal and failing hearts (222-226), with apelin-knockout mice displaying significant and progressive LV systolic dysfunction (227).

In humans, plasma apelin concentrations are reduced in patients following acute myocardial infraction (228), both plasma (229-233) and myocardial $(230,233,234)$ levels are significantly reduced in patients with advanced CHF. Small studies have demonstrated that improving or augmenting cardiac performance with LVAD (230) or cardiac resynchronization therapy $(231,234)$ leads to a significant increase in serum apelin concentrations and myocardial apelin and APJ levels, suggesting that apelin may hold promise as a marker of reverse remodeling in CHF.

\section{g) Urocortin}

Urocortin I, II and III are peptides with significant structural homology to the important mediator of the pituitary-adrenal glucocorticoid axis, corticotrophin-releasing factor (CRF) (235). They are the ligands for the CRF-1 and CRF-2 receptors and exhibit inotropic (236), vasodilatory $(237,238)$, cardioprotective $(239,240)$ and beneficial hemodynamic effects in animal models of heart failure (241-245).

To date, the only study to investigate circulating urocortin concentrations in $\mathrm{CHF}$ demonstrated a significant increase compared with age-and sex-matched healthy controls (246). Further clarification of the effect of CHF on plasma urocortin concentrations is necessary to establish its potential as a biomarker in this syndrome.

\section{METABOLIC BIOMARKERS}

\section{a) Coenzyme $Q 10(\mathrm{CoQ} 10)$}

$\mathrm{CoQ} 10$ is a quinone that is a crucial component of cellular respiration in the synthesis of adenosine triphosphate via the mitochondrial electron transfer chain (247). Myocardial CoQ10 levels have long been known to be reduced in CHF and correlate with worsening NYHA status (248). More recently, plasma CoQ10 levels were shown to be reduced and independently predictive of mortality in CHF patients (249). There is some evidence that therapeutic upregulation of CoQ10 in CHF 
may result in an increase in cardiac output and LV ejection fraction (250), and the results of a large international trial are awaited (251).

\section{b) Adiponectin}

Adiponectin is a 244-amino acid fat-derived peptide hormone with a role in metabolic regulation. It is abundantly produced by adipose tissue and less so by the myocardium, with plasma concentrations negatively correlating with body fat and BMI $(252,253)$. Preclinical studies have demonstrated antiapoptotic, antiatherosclerotic and antihypertrophic properties, as well as the ability to improve endothelial function (252). Plasma concentrations are reduced in patients with ischemic heart disease but are increased in patients with acutely decompensated heart failure in whom they predict prognosis (254). Adiponectin synthesis is stimulated by the natriuretic peptides (255) and, as such, myocardial production and circulating levels of adiponectin are also significantly raised in CHF patients in whom they correlate closely with BNP levels and again predict prognosis (256).

\section{NOVEL INFLAMMATORY BIOMARKERS IN HEART FAILURE}

Chronic heart failure is now recognized as a chronic inflammatory state, with immune activation and proinflammatory cytokines playing instrumental roles in both the development and the progression of the syndrome (257). Recent advances have identified novel inflammatory mediators with putative roles in CHF and, therefore, a subsequent interest is emerging in the utilization of these mediators as biomarkers.

a) $S T 2 \& I L-33$

The receptor ST2 is a member of the Toll-like/IL-1 receptor superfamily (258) with transmembrane and extracellular isoforms, the latter of which is soluble and can circulate in the plasma (259). ST2 gene expression is significantly upregulated following acute myocardial infarction in rat cardiomyocytes (260). In 2005, the ligand for ST2 was identified as IL-33 (261). IL-33 antagonizes Ang II-induced cardiomyocyte hypertrophy and fibrosis with ST2-knockout mice, displaying greater LV hypertrophy, dilatation, fibrosis and shortened survival following aortic constriction than wildtype controls (262). Therefore, it appears that the IL-33/ST2 system plays a role in regulating the protective myocardial response to pressure overload. Serum soluble ST2 levels are raised in humans following acute myocardial infarction in whom they negatively correlate with LV ejection fraction, and independently predict both mortality and progression to CHF $(260,263)$. Circulating ST2 levels are also a strong and independent predictor of mortality in patients with acutely decompensated heart failure (264-267), as well as advanced CHF (268). Further studies are awaited in order to determine the full utility of ST2 as a biomarker in CHF.

\section{b) Growth differentiation factor-15}

Growth differentiation factor- 15 is a member of the TGF- $\beta$ superfamily whose levels are increased by oxidative stress, myocardial ischemia and inflammatory cytokines, and protects against reperfusion injury (269). It is not normally expressed in the myocardium but is induced in animal models of pressure overload and ischemia, where it promotes antiapoptotic, antihypertrophic and antiremodeling effects $(269,270)$. Circulating levels are significantly raised in CHF patients in whom they independently predict mortality and positively correlate with age, NYHA class and BNP, whilst negatively correlating with renal function and LV ejection fraction (271).

\section{c) Pentraxin-3}

This acute-phase protein is a member of the long pentraxin family and is produced by macrophages, monocytes, vascular endothelium, vascular smooth muscle and adipocytes in response to proinflammatory mediators (272). These include TNF- $\alpha$, IL- 1 and bacterial endotoxin. In humans, plasma pentraxin-3 levels are raised following acute myocardial infarction and were stronger predictors of 3-month mortality in 734 postmyocardial infarction patients than cardiac troponin $\mathrm{T}$, creatine kinase or NT-proBNP in a multivariable analysis (273). Plasma concentrations are similarly raised in CHF and independently predict mortality in these patients $(274,275)$.

\section{d) Osteopontin}

This is a glycoprotein that is expressed in cardiomyocytes and fibroblasts, and can exist as an extracellular matrix molecule or as a soluble circulating cytokine. Myocardial osteopontin levels are upregulated by Ang II (276) and are raised in both animal (277-279) and human heart failure $(280,281)$. Circulating osteopontin concentrations 
were raised in 420 CHF patients in whom they correlated with worsening NYHA class and independently predicted 4 - year mortality (282).

e) Cardiotrophin-1

Cardiotrophin-1 is a member of the IL-6 family of cytokines. It is expressed in various tissues including the myocardium (283) and is secreted in response to myocardial stretch (284). Preclinical studies have suggested that CT-1 is negatively inotropic (285) and antiapoptotic, and also promotes the development of LV hypertrophy (286). Plasma concentrations are raised in CHF correlating positively with LV mass, $I L-6, T N F-\alpha$ and negatively with $L V$ ejection fraction 287-288). Circulating levels independently predict mortality in these patients (289).

\section{OTHER NOVEL BIOMARKERS}

\section{FOR HEART FAILURE}

a) Cystatin $C$

Cystatin $\mathrm{C}$ is a 120-amino acid serine protease inhibitor and is ubiquitously expressed in human tissue (290). It is freely filtered at the glomerulus and, therefore, is a surrogate marker of renal perfusion and glomerular filtration. Plasma levels are increased in patients presenting with acutely decompensated heart failure and independently predict mortality at 1 year (291). Plasma concentrations predict the development of CHF and all-cause mortality in patients with coronary artery disease (292). They are also independently predictive of mortality in patients with CHF and appear to be of greater prognostic value to creatinine in older patients $(293,294)$.

\section{b) Troponin}

Prevalence of troponin elevation in chronic and acute decompensated heart failure is established. Prognostic significance of troponin in this clinical context is emerging. Many studies, to date, have been performed using limited multivariable analyses. Large prospective studies evaluating the incremental prognostic value of troponin over established predictors of risk are required. The combination of troponin and other predictors of risk may help to improve the challenge of risk stratification in heart failure (295)

\section{c) G-protein-coupled receptor kinase (GRK)}

The key role that GRKs play in GPCR signaling and modulation suggests that changes in their cellular complement and functionality would strongly affect
GPCR function, as has been described in several pathological conditions, such as hypertension (HTN) (296), insulin resistance (IRES) (297), congestive heart failure (CHF) (298) and coronary artery disease (CAD) (299). The heart contains GRK2, GRK3 and GRK5, of which GRK2 is the most abundantly expressed $(300,301)$.

At present, there is much evidence demonstrating the important role of GRK levels observed in white blood cells as a biomarker of cardiac dysfunction, in particular in CHF (302-304). Therefore, lymphocytes may provide a surrogate for monitoring cardiac GRK2 in human CHF, and measuring GRK2 in the blood of CHF patients may potentially become a marker for monitoring changes in left ventricular (LV) function and, importantly, may monitor response to therapy (305).

The increase in GRK2 levels appear to be proportionate to the decrease in cardiac function. This feature indicates the use of GRK2 as a biomarker at the time of admission in the emergency room: the higher levels of peripheral white cells content in GRK2 may help to discriminate those patients with a poor cardiac performance who are in need of more aggressive therapy (306).

\section{d) Resistin}

Resistin, a novel metabolic marker, has been associated with the severity of and prognosis in prevalent $\mathrm{HF}$, and also helps to predict incident $\mathrm{HF}$. These relationships may be mediated via insulin resistance, inflammation, direct effects on myocytes or other yet to be discovered pathways. Future roles for resistin may both help stratify risk for incidental $\mathrm{HF}$, prognosticate prevalent $\mathrm{HF}$, and possibly help develop newer therapies (307).

\section{e) Cytokines and Matrix Metalloproteinase (MMP)}

$\mathrm{HF}$ is accompanied by the upregulation of bioactive signaling molecules, known as cytokines, and a family of downstream proteases, MMPs. It is now apparent that these molecules contribute to adverse myocardial remodeling during HF. Elevated levels of cytokines and MMPs exist in the myocardium and can subsequently spill over into the systemic circulation (308).

Specifically, TNFRI, IL-6, MMP-2 and TIMP-1 levels were elevated in HF patients and correlated with NYHA functional status (309-312). Moreover, circulating levels of TNF, TNFRI, TNFRII, MMP-3 and TIMP-1 were independent predictors of patient 
mortality $(309,311,313-316)$. These clinical studies suggest that cytokines and MMPs may be used as biomarkers for the prognosis of HF. This article has also identified distinct differences in the circulating levels of cytokines and MMPs in DHF and SHF phenotypes. Generally, SHF patients have greater levels of circulating cytokines (TNF, TNFRI and IL10) and MMPs (MMP-1 and -2) than DHF patients $(310,317,318)$. Results from these initial clinical studies comparing DHF with SHF patients suggest that prospective HF clinical studies should account for differences in HF phenotypes. The clinical need to refine diagnosis, patient stratification, as well as therapeutic monitoring has sparked the continuous search for biomarkers as useful tools in heart failure management (180).

\section{Novel Biomarkers for Atrial Fibrilation}

It is anticipated that over the next 4 decades, the prevalence of atrial fibrillation (AF) will increase dramatically owing to an aging population, improved therapies, and longer survival with heart disease $(319,320)$. AF is associated with higher rates of stroke and hospitalization $(321,322)$, diminished quality of life (323), and significant mortality (324). The identification of risk factors for developing $\mathrm{AF}$ is an important epidemiological task with potential implications for public health $(325,326)$.

Well-established clinical risk factors for $\mathrm{AF}$ other than age and sex are body mass index, hypertension, and cardiovascular disease, including valvular disease and heart failure (327-329); however, these risk factors do not explain all cases of $\mathrm{AF}$, which suggests a need for improvement in risk prediction and understanding of the pathophysiology of $\mathrm{AF}$ (330). Blood and urinary biomarkers are potential tools to enhance $\mathrm{AF}$ risk prediction and to provide insights into the pathophysiology of the disease. On the basis of biological plausibility and prior reports, biomarkers were chosen to represent distinct pathophysiological pathways, including inflammation (C-reactive protein [CRP] and fibrinogen) $(331,332)$, neurohormonal activation (B-type natriuretic peptide [BNP] and $\mathrm{N}$-terminal proatrial natriuretic peptide [N-ANP]) $(333,334)$ oxidative stress and endothelial dysfunction (homocysteine) (335), the reninangiotensin-aldosterone system (renin and aldosterone) (334), thrombosis and endothelial function (D-dimer and plasminogen activator inhibitor type 1) $(336,337)$, and microvascular damage (urinary albumin excretion) (338).

$\mathrm{BNP}$ is a predictor of incident $\mathrm{AF}$ and improves risk stratification based on well-established clinical risk factors. Whether knowledge of BNP concentrations may be used to target individuals at risk of $\mathrm{AF}$ for more intensive monitoring or primary prevention requires further investigation (339).

A study on AF has demonstrated elevated levels of YKL-40 compared with healthy controls (340). In addition, YKL-40 was related to whether the patients had permanent or persisting $\mathrm{AF}$, and thereby the burden of $\mathrm{AF}$ (341).

\section{Conclusion}

Cardiac biomarkers have proved extremely valuable for diagnosis, risk stratification, and treatment of patients in the emergency setting. Novel studies are currently underway using biomarkers to predict long-term outcomes and mortality in patients with stable coronary heart disease. There is also much interest in the use of cardiac biomarkers to provide further risk stratification, especially in those patients who are at an intermediate risk per Framingham score.

To be clinically useful, a biomarker must provide incremental information that both adds to existing clinical findings and is useful in the clinical care of the patient. An ideal marker is one in which there is a specific, easily measurable increase that clearly aligns with a predictable outcome be it evidence of ischemia, inflammation, myocardial necrosis, plaque rupture, plaque destabilization, or heart failure. It remains a major challenge for researchers and clinicians to show whether newer and future biomarkers are useful for guiding specific treatment algorithms.

\section{References:}

1. American HeartAssociation. Heart Disease and Stroke Statistics: 2005 Update. Dallas, Tex: American Heart Association; 2005.

2. Pearson TA, Blair SN, Daniels SR, et al. AHA guidelines for primary prevention of cardiovascular disease and stroke: 2002 update: consensus panel guide to comprehensive risk reduction for adult patients without coronary or other atherosclerotic vascular diseases. Circulation. 2002;106:388-91.

3. Berenson GS, Srinivasan SR, Bao W, Newman WP, Tracy RE, Wattigney WA. Association between multiple cardiovascular risk factors and atherosclerosis in children and young adults: the Bogalusa Heart Study. N Engl J Med. 1998;338:1650-6.

4. Raitakari OT, Juonala M, Kahonen M, et al. Cardiovascular risk factors in childhood and carotid artery intima-media 
thickness in adulthood: the Cardiovascular Risk in Young Finns Study. JAMA. 2003;290:2277-83.

5. Kuller LH, Shemanski L, Psaty BM, et al. Subclinical disease as an independent risk factor for cardiovascular disease. Circulation. 1995; 92:720-6.

6. Psaty BM, Furberg CD, Kuller $\mathrm{LH}$, et al. Traditional risk factors and subclinical disease measures as predictors of first myocardial infarction in older adults: the Cardiovascular Health Study. Arch Intern Med. 1999;159:1339-47.

7. Guidry UC, Evans JC, Larson MG, Wilson PWF, Murabito JM, Levy D. Temporal trends in event rates after Q-wave myocardial infarction: the Framingham Heart Study. Circulation. 1999;100:2054-9.

8. Jokhadar M, Jacobsen SJ, Reeder GS, Weston SA, Roger VL. Sudden death and recurrent ischemic events after myocardial infarction in the community. Am J Epidemiol. 2004;159:1040-6.

9. Naghavi M, Libby P, Falk E, et al. From vulnerable plaque to vulnerable patient: a call for new definitions and risk assessment strategies: part I. Circulation. 2003;108:166472.

10. Naghavi $M$, Libby $P$, Falk $E$, et al. From vulnerable plaque to vulnerable patient: a call for new definitions and risk assessment strategies: part II. Circulation. 2003;108:1772-8.

11. Biomarkers Definitions Working Group. Biomarkers and surrogate endpoints: preferred definitions and conceptual framework. Clin Pharmacol Ther. 2001;69:89-95.

12. Fox N, Growdon JH. Biomarkers and surrogates. Neuro Rx. 2004;1:181.

13. Morrow DA, de Lemos JA. Benchmark for the Assessment of Novel Cardiovascular Biomarkers. Circulation 2007, 115: 949-52.

14. Moons KGM. Criteria for scientific evaluation of novel markers: a perspective. Clin Chem 2010, 56: 537-41.

15. Tardif JC, Heinonen T, Orloff D, Libby P. Vascular Biomarkers and Surrogates in Cardiovascular Disease. Circulation 2006, 113: 2936-42.

16. Prentice RL. Surrogate endpoints in clinical trials: definition and operational criteria. Stat Med. 1989;8:431-40.

17. Lander ES, Linton LM, Birren B, et al. International Human Genome Sequencing Consortium. Initialvsequencing and analysis of the human genome. Nature. 2001;409:860921.

18. Altshuler D, Brooks LD, Chakravarti A, Collins FS, Daly MJ, Donnelly P. A haplotype map of the human genome. Nature. 2005;437: 1299-1320.

19. Marko-Varga G, Lindberg H, Lofdahl CG, Jonsson P, Hansson L, Dahlback M, Lindquist E, Johansson L, Foster M, Fehniger TE. Discoveryvof biomarker candidates within disease by protein profiling:vprinciples and concepts. J Proteome Res. 2005;4:1200-12.

20. Westont AD, Hood L. Systems biology, proteomics, and the future of health care: toward predictive, preventative, and personalized medicine. J Proteome Res. 2004;3:179-96.

21. Vasan RS. Biomarkers of Cardiovascular Disease. Molecular Basis and Practical Considerations. Circulation 2006, 113: 2335-62.

22. Lander ES, Schork NJ. Genetic dissection of complex traits. Science. 1994;265:2037-48.

23. Napoli C, Lerman LO, Sica V, Lerman A, Tajana G, de Nigris F. Microarray analysis: a novel research tool for cardiovascular scientists and physicians. Heart. 2003;89:597-604.

24. Cook SA, Rosenzweig A. DNA microarrays: implications for cardiovascular medicine. Circ Res. 2002;91:559-64.

25. Steinmetz LM, Davis RW. Maximizing the potential of functional genomics. Nat Rev Genet. 2004;5:190-201.
26. Gerszten RE, Carr SA, Sabatine M. Integration of proteomicbased tools for improved biomarkers of myocardial injury. Clin Chem 2010; 56: 194-201.

27. Bartunek J. Biomarkers for coronary artery disease: mission impossible? Biomarkers Med 2010; 4: 339-40.

28. Liu MY, Xydakis AM, Hoogeveen RC, et al. Multiplexed analysis of biomarkers related to obesity and the metabolic syndrome in human plasma, using the Luminex-100 system. Clin Chem 2005; 51:1102-9.

29. National Committee for Clinical Laboratory Standards (NCCLS). Evaluation of precision performance of clinical chemistry devices; approved guideline. Wayne, PA: NCCLS, 1999:142.

30. National Committee for Clinical Laboratory Standards (NCCLS). Evaluation of the linearity of quantitative measurement procedures: a statistical approach; approved guideline. Wayne, PA: NCCLS, 2003.

31. National Committee for Clinical Laboratory Standards (NCCLS). Interference testing in clinical chemistry; Approved guideline. Wyane, PA: NCCLS, 2002.

32. (ISO) ISO Standard. Accuracy (trueness and precision) of measurement methods and results (ISO 5725)-Part 1: general principles and definitions. Geneva: ISO, 1994.

33. Solberg HE. International Federation of Clinical Chemistry (IFCC), Scientific Committee, Clinical Section, Expert Panel on Theory of Reference Values, and International Committee for Standardization in Haematology (ICSH). Standing Committee on Reference Values. Approved Recommendation. (1986) on the theory of reference values. Part 1. The concept of reference values. J Clin Chem Clin Biochem 1987;25:337-42.

34. Solberg HE, PetitClerc C. International Federation of Clinical Chemistry (IFCC), Scientific Committee, Clinical Section, Expert Panel on Theory of Reference Values. Approved recommendation. (1988) on the theory of reference values. Part 3. Preparation of individuals and collection of specimens for the production of reference values. J Clin Chem Clin Biochem 1988;26:593-8.

35. Vitzthum F, Behrens F, Anderson NL, Shaw JH. Proteomics: from basic research to diagnostic application: a review of requirements and needs. J Proteome Res 2005; 4: 108697.

36. Bell KJ, Irwig L, Craig JC, Macaskill P. Use of randomised trials to decide when to monitor response to new treatment. BMJ 2008;336: 361-5.

37. Lassere MN, Johnson KR, Boers M, Tugwell P, Brooks P, Simon $\mathrm{L}$, et al. Definitions and validation criteria for biomarkers and surrogate endpoints: development and testing of a quantitative hierarchical levels of evidence schema. J Rheumatol 2007;34:607-15.

38. Barker PE. Cancer biomarker validation: standards and process: roles for the National Institute of Standards and Technology (NIST). Ann N Y Acad Sci. 2003;983:142-50.

39. Schulte PA, Perera FP. Validation. In: Schulte PA, Perera FP, eds. Molecular Epidemiology: Principles and Practice. San Diego, Calif: Academic Press; 1993:79-107.

40. Pepe MS, Etzioni R, Feng Z, et al. Phases of biomarker development for early detection of cancer. J Natl Cancer Inst. 2001;93:1054-61.

41. World Health Organization Fact sheet No. 317 September 2009 www.who.int/mediacentre/factsheets/fs $317 /$ en/index.html

42. Dzau VJ: Markers of malign across the cardiovascular continuum: interpretation and application. Circulation 2004; 109(25 Suppl. 1): IV1-IV2.

43. Valentin E. Aterovax. Biomarkers Med 2010; 4: 345-50.

44. Evans A, Salomaa V, Kulathinal $S$, et al. MORGAM (an international pooling of cardiovascular cohorts). Int J Epidemiol. 2005;34:21-7. 
45. Kulathinal S, Niemela" M, Kuulasmaa K, contributors from Participating Centres, for the MORGAM Project. Description of MORGAM cohorts (2005). Available at: http://www. ktl.fi/ publications/morgam/cohorts/index.html, URN: NBN: fife20051214.

46. Blankenberg S, Zeller T, Saarela O, et al. Contribution of 30 Biomarkers to 10 - year Cardiovascular Risk Estimation in 2 Population Cohorts. The MONICA, Risk, Genetic, Archiving, and Monograph (MORGAM) Biomarker Project. Circulation 2010; 121: 2388-97.

47.Castelli WP, Anderson K, Wilson PW, Levy D. Lipids and risk of coronary heart disease. The Framingham Study. Ann Epidemiol 1992;2:23-8.

48. Sacks FM, Pfeffer MA, Moye LA, Rouleau JL, Rutherford JD, Cole TG, et al. The effect of pravastatin on coronary events after myocardial infarction in patients with average cholesterol levels. Cholesterol and Recurrent Events Trial investigators. N Engl J Med 1996;335:1001-9.

49. Downs JR, Clearfield M, Weis S, Whitney E, Shapiro DR, Beere PA, et al. Primary prevention of acute coronary events with lovastatin in men and women with average cholesterol levels: results of AFCAPS/TexCAPS. Air Force/ Texas Coronary Atherosclerosis Prevention Study. JAMA 1998;279: 1615-22.

50. Brewer HB Jr, Remaley AT, Neufeld EB, Basso F, Joyce C. Regulation of plasma high-density lipoprotein levels by the ABCA1 transporter and the emerging role of high-density lipoprotein in the treatment of cardiovascular disease. Arterioscler Thromb Vasc Biol 2004;24:1755-60.

51. Briel M, Ferreira-Gonzalez I, You JJ, Karanicolas PJ, Akl EA, Wu $\mathrm{P}$, et al. Association between change in high density lipoprotein cholesterol and cardiovascular disease morbidity and mortality: systematic review and meta-regression analysis. BMJ 2009;338:92.

52. Nissen SE, Tardif JC, Nicholls SJ, Revkin JH, Shear CL, Duggan WT, et al. Effect of torcetrapib on the progression of coronary atherosclerosis. N Engl J Med 2007;356:1304-16.

53. Ansell BJ, Fonarow GC, Fogelman AM. The paradox of dysfunctional high-density lipoprotein. Curr Opin Lipidol 2007; 18:427-34.

54. Rader DJ. Molecular regulation of HDL metabolism and function: implications for novel therapies. J Clin Invest 2006;116:3090-100.

55. Remaley AT, Warnick GR. High-density lipoprotein: what is the best way to measure its antiatherogenic potential? Expert Opin Med Diagn 2008;2: 773-88.

56. Sethi AA, Sampson M, Warnick R, et al. High Pre- $\beta 1$ HDL Concentrationand Low Lecithin: CholesterolAcyltransferase Activities Are Strong Positive Risk Markers for Ischemic Heart Disease and Independent of HDL - Cholesterol. Clin Chem 2010; 56: 1128-37.

57. Brown J, Nallamshetty S, Plutzky J. Intersecting Vectors of Basic Science Research and Clinical Medicine: LOX-Clin Chem 2010; 56: 499-501.

58. Inoue N, Okamura T, Kokubo $\mathrm{Y}$, et al. LOX index, a novel predictive biochemical marker for coronary heart disease and stroke. Clin Chem $2010 ; 56: 550-8$.

59. Erqou S, Kaptoge S, Perry PL, et al. Lipoprotein(a) concentration and the risk of coronary heart disease, stroke, and nonvascular mortality. JAMA 2009, 302: 412-23.

60. Kamstrup PR, Nordestgaard BG. Lipoprotein(a) should be taken much more seriously. Biomarkers Med 2009; 3: 439-41.

61. Lambeau G, Gelb MH: Biochemistry and physiology of mammalian secreted phospholipases A2. Ann. Rev. Biochem. 2008; 77,495-520.

62. Rosenson RS, Hislop C, McConnell D et al:: Effects of 1-Hindole-3-glyoxamide (A-002) on concentration of secretory phospholipase A2 (PLASMA study): a Phase II doubleblind, randomised, placebo-controlled trial. Lancet 2009;
373: $649-58$.

63. Knockaert DC, Buntinx F, Stoens N, Bruyninckx R, Delooz $\mathrm{H}$. Chest pain in the emergency department: the broad spectrum of causes. Eur J Emerg Med 2002; 9: 25-30.

64. Karmen A, Wroblewski F, Ladue JS. Transaminase activity in human blood, J Clin Invest 1955; 34: 126-31.

65. Anderson JL, Adams CD, Antman EM, et al. ACC/AHA 2007 guidelines for the management of patients with unstable angina/non ST-elevation myocardial infarction: a report of the American College of Cardiology/American Heart Association Task Force on Practice Guidelines. Circulation 2007; 116: e148-e304.

66. Ross R. Atherosclerosis-an inflammatory disease. N Engl J Med 1999; 340: 115-26.

67. Kunsch C, Medford RM. Oxidative stress as a regulator of gene expression in the vasculature. Circ Res 1999; 85: 753-66.

68. Packard RR, Libby P. Inflammation in atherosclerosis: from vascular biology to biomarker discovery and risk prediction. Clin Chem 2008; 54: 24-38.

69. Uno K, Nicholls SJ. Biomarkers of inflammation and oxidative stress in atherosclerosis. Biomarkers Med 2010; 4: 36173.

70. Witztum JL, Steinberg D. Role of oxidized low density lipoprotein in atherogenesis. J Clin Invest 1991; 88: 1785-92.

71. Goldstein JL, Ho YK, Basu SK, Brown MS. Binding site on macrophages that mediates uptake and degradation of acetylated low density lipoprotein, producing massive cholesterol deposition. Proc Natl Acad USA 1979; 76: 333-7.

72. Rizvi AA. Cytokine biomarkers, endothelial inflammation, and atherosclerosis in the metabolic syndrome: emerging concepts. Am J Med Sci 2009; 338: 310-8.

73. Csiszar A, Wang M, Lakatta EG, Ungvari Z. Inflammation and endothelial dysfunction during aging: role of NF kB. J Appl Physiol 2008; 105: 1333-41.

74. Stary HC, Chandler AB, Glagov S, et al. A definition of initial, fatty streak, and intermediate lesions of atherosclerosis. A report from the Committee on Vascular Lesions of the Council on Arteriosclerosis, American Heart Association. Circulation 1994; 89: 2462-78.

75. Hazen SL, Heinecke JW. 3 chlorotyrosine, a specific marker of myeloperoxidase-catalyzed oxidation, is markedly elevated in low density lipoprotein isolated from human atherosclerotic intima. J Clin Invest 1997; 99: 2075-81.

76. Schindhelm RK, van der Zwan LP, Teerlink T, Scheffer PG. Myeloperoxidase: A useful biomarker for cardiovascular disease risk stratification? Clin Chem 209; 55: 1462-70.

77. Lin HS, Jenner AM, Ong CN, Huang SH, Whiteman M, Halliwell B. A high-throughput and sensitive methodology for the quantification of urinary 8-hydroxy-2' deoxyguanosine: measurement with gas chromatography-mass spectrometry after single solid-phase extraction. Biochem J 2004; 380: 541-8.

78. Morrow JD. Quantification of isoprostanes as indices of oxidant stress and the risk of atherosclerosis in humans. Arterioscler Thromb Vasc Biol 2005; 25: 279-86.

79. Stephens JW, Khanolkar MP, Bain SC. The biological relevance and measurement of plasma markers of oxidative stress in diabetes and cardiovascular disease. Atherosclerosis 2009; 202: 321-9.

80. Tsukahara H. Biomarkers for oxidative stress: clinical application in pediatric medicine. Curr Med Chem 2007; 14: 339-51.

81. Yamawaki $H$, Haendeler J, Berk BC. Thioredoxin: a key regulator of cardiovascular homeostasis. Circ Res 2001; 93: 1029 33.

82. Durrington PN, Mackness B, Mackness MI. Paraoxonase and atherosclerosis. Arterioscler Thromb Vasc Biol. 2001; 21: 473-80. 
83. Dhamrait SS, Stephens JW, Cooper JA et al. Cardiovascular risk in healthy men and markers of oxidative stress in diabetic men are associated with common variation in the gene for uncoupling protein 2. Eur Heart J 2004; 25: 468-75.

84. Boger RH, Bode-Boger SM, Szuba A et al. Asymmetric dimethylarginine (ADMA): a novel risk factor for endothelial dysfunction: its role in hypercholesterolemia. Circulation 1998; 98: 1842-7.

85. Boger RH. Asymmetric dimethylarginine (ADMA): a novel risk marker in cardiovascular medicine and beyond. Ann Med 2006: 38: 126-36.

86. Danesh J, Wheeler JG, Hirschfield GM et al. C reactive protein and other circulating markers of inflammation in the prediction of coronary heart disease. N Engl J Med 2004; 350: 1387-97.

87. Boekholdt SM, Hack CE, Sandhu MS et al. C reactive protein levels and coronary artery disease incidence and mortality in apparently healthy men and women: the EPIC-Norfolk prospective population study 1993-2003. Atherosclerosis 2006; 187: 415-22.

88. Meuwese MC, Stroes ES, Hazen SLetal. Serummyeloperoxidase levels are associated with the future risk of coronary artery disease in apparently healthy individuals: the EPIC-Norfolk prospective population study. J Am Coll Cardiol. 2007; 50: 159-65.

89. Ballantyne CM, Hoogeveen RC, Bang $\mathrm{H}$ et al. Lipoproteinassociated phospholipase $\mathrm{A} 2$, high-sensitivity $\mathrm{C}$ reactive protein, and risk for incident ischemic stroke in middle-aged men and women in the atherosclerosis risk in communities (ARIC) study. Arch Intern Med 2005; 165: 2479-84.

90. Danesh J, Kaptoge S, Mann AG et al. Long-term interleukin 6 levels and subsequent risk of coronary heart disease: two new prospective studies and a systematic review. PLoS Med 2008; 5: e78.

91. Montero I, Orbe J, Varo $\mathrm{N}$ et al. C reactive protein induces matrix metalloproteinase 1 and 10 in human endothelial cells: implications for clinical and subclinical atherosclerosis. J Am Coll Cardiol. 2006; 47: 1369-78.

92. Venugopal SK, Devaraj S, Jialal I. Effect of $C$ reactive protein on vascular cells: evidence for a proinflammatory, proatherogenic role. Curr Opin Nephrol Hypertens 2005; 14: 33-7.

93. Scirica BM, Morrow DA. Is C reactive protein an innocent bystander or proatherogenic culprit? The verdict is still out. Circulation 2006; 113: 2128-34; discussion 2151.

94. Verma S, Devaraj S, Jialal I. Is C reactive protein an innocent bystander or proatherogenic culprit? $\mathrm{C}$ reactive protein promotes atherothrombosis. Circulation 2006; 113: 2135 50; discussion 2150.

95. Lee H, Shi W, Tontonoz P et al. Role for peroxisome proliferatoractivated receptor a in oxidized phospholipid-induced synthesis of monocyte chemotactic protein 1 and interleukin 8 by endothelial cells. Circ Res 2000; 87: 516-21.

96. Zhang R, Brennan Ml, Fu X et al. Association between myeloperoxidase levels and risk of coronary artery disease. JAMA 2001; 286: 2136-42.

97. Podrez EA, Schmitt D, Hoff HF, Hazen SL:Myeloperoxidasegenerated reactive nitrogen species convert LDL into an atherogenic form in vitro. J Clin Invest 1999; 103: $1547-$ 60.

98. Hazen SL, Zhang R, Shen Z et al. Formation of nitric oxidederived oxidants by myeloperoxidase in monocytes: pathways for monocyte-mediated protein nitration and lipid peroxidation in vivo. Circ Res 1999; 85: 950-8.

99. Zheng L, Nukuna B, Brennan ML et al..:Apolipoprotein A 1 is a selective target for myeloperoxidase-catalyzed oxidation and functional impairment in subjects with cardiovascular disease. J Clin Invest 2004; 114: 529-41.

100. Caslake MJ, Packard CJ. Lipoprotein-associated phospholipase
A2 (platelet-activating factor acetylhydrolase) and cardiovascular disease. Curr Opin Lipidol 2003; 14: 34752.

101. Hase M, Tanaka M, Yokota M, Yamada Y. Reduction in the extent of atherosclerosis in apolipoprotein E-deficient mice induced by electroporation-mediated transfer of the human plasma platelet-activating factor acetylhydrolase gene into skeletal muscle. Prostaglandins Other Lipid Mediat. 2002; 70: $107-18$.

102. Garza CA, Montori VM, Mcconnell JP, Somers VK, Kullo IJ, Lopez-Jimenez F. Association between lipoproteinassociated phospholipase A2 and cardiovascular disease: a systematic review. Mayo Clinic Proc 2007; 82: 159-65.

103. Schonbeck $U$, Libby $P$. CD40 signaling and plaque instability. Circ Res 2001; 89: 1092-103.

104. Rizvi M, Pathak D, Freedman JE, Chakrabarti S. CD40-CD40 ligand interactions in oxidative stress, inflammation and vascular disease. Trends Mol Med 2008; 14: 530-8.

105. Muller O, Barbato E, De Bruyne B, Bartunek J. Biomarkers of vulnerable plaque: the missing link with ischemia. Biomarkers Med 2010; 4: 375-83.

106. Bar-Or D, Curtis G, Rao N, Bampos N, Lau E. Characterization of the $\mathrm{Co} 2+$ and $\mathrm{Ni2}+$ binding amino-acid residues of the $\mathrm{N}$ terminus of human albumin. An insight into the mechanism of a new assay for myocardial ischemia. Eur $\mathrm{J}$ Biochem 2001; 268: 42-7.

107. Bar-Or D, Lau E, Winkler JV. A novel assay for cobalt-albumin binding and its potential as a marker for myocardial ischemia - a preliminary report. J Emerg Med 2000; 19: 311-5.

108. Chan B, Dodsworth N, Woodrow J, Tucker A, Harris R. Sitespecific $\mathrm{N}$ terminal auto-degradation of human serum albumin. Eur J Biochem 1995; 227: 524-8.

109. Roy D, Quiles J, Gaze DC, Collinson P, Kaski JC, Baxter GF. Role of reactive oxygen species on the formation of the novel diagnostic marker ischaemia modified albumin. Heart 2006; 92: 113-4.

110.Bar-OrD, Winkler JV, Vanbenthuysen K, Harris L, LauE, HetzelFW: Reduced albumin-cobalt binding with transient myocardial ischemia after elective percutaneous transluminal coronary angioplasty: a preliminary comparison to creatine kinase MB, myoglobin, and troponin I. Am Heart J 2003; 141: 98591.

111.Sinha MK, Gaze DC, Tippins JR, Collinson PO, Kaski JC. Ischemia modified albumin is a sensitive marker of myocardial ischemia after percutaneous coronary intervention. Circulation 2003; 107: 2403-5.

112.Richieri GV, Ogata RT, Kleinfeld AM. A fluorescently labeled intestinal fatty acid binding protein. Interactions with fatty acids and its use in monitoring free fatty acids. J Biol Chem 1992; 267: 23495-501.

113.Cantor WJ, Kim HH, Jolly S et al. B type natriuretic peptide and serum unbound free fatty acid levels after contemporary percutaneous coronary intervention. J Invasive Cardiol 2008; 20: 186-8.

114.Kleinfeld AM, Prothro D, Brown DL, Davis RC, Richieri GV, DeMaria A. Increases in serum unbound free fatty acid levels following coronary angioplasty. Am J Cardiol 1996; 78: $1350-4$.

115.Danne O, Mockel M. Choline in acute coronary syndrome: an emerging biomarker with implications for the integrated assessment of plaque vulnerability. Expert Rev Mol Diagn 2010; 10: 159-71.

116.LeLeiko RM, Vaccari CS, Sola S et al. Usefulness of elevations in serum choline and free $\mathrm{F} 2$ isoprostane to predict 30 day cardiovascular outcomes in patients with acute coronary syndrome. Am J Cardiol 2009; 104: 638-43.

117.de Lemos JA, McGuire DK, Drazner MH. B type natriuretic peptide in cardiovascular disease. Lancet 2003; 362: 316-22.

118.Marumoto K, Hamada M, Hiwada K. Increased secretion of atrial 
and brain natriuretic peptides during acute myocardial ischaemia induced by dynamic exercise in patients with angina pectoris. Clin Sci (Lond.) 1995; 88: 551-6.

119.Kyriakides ZS, Markianos M, Michalis L, Antoniadis A, Nikolaou $\mathrm{NI}$, Kremastinos DT. Brain natriuretic peptide increases acutely and much more prominently than atrial natriuretic peptide during coronary angioplasty. Clin Cardiol 2000; 23: 285-8.

120. Mega JL, Morrow DA, De Lemos JA et al. B type natriuretic peptide at presentation and prognosis in patients with ST segment elevation myocardial infarction: an ENTIRE TIMI 23 substudy. J Am Coll Cardiol 2004; 44: 335-9.

121. de Lemos JA, Morrow DA, Bentley JH et al:: The prognostic value of B type natriuretic peptide in patients with acute coronary syndromes. N Engl J Med 2001; 345: 1014-21.

122. Omland T, Sabatine MS, Jablonski KA et al. Prognostic value of B type natriuretic peptides in patients with stable coronary artery disease: the PEACE trial. J Am Coll Cardiol 2007; 50: 205-14

123. Kragelund $C$, Gronning $B$, Kober $L$, Hildebrandt $P$, Steffensen R. N terminal pro-B type natriuretic peptide and long-term mortality in stable coronary heart disease. N Engl J Med 2005; 352: 666-75.

124. Bibbins-Domingo K, Gupta R, Na B, Wu AH, Schiller NB, Whooley MA. $\mathrm{N}$ terminal fragment of the prohormone brain-type natriuretic peptide (NT proBNP), cardiovascular events, and mortality in patients with stable coronary heart disease. JAMA 2007; 297: 169-76.

125. Deo R, Shlipak MG, Ix JH, Ali S, Schiller NB, Whooley MA: Association of cystatin $\mathrm{C}$ with ischemia in patients with coronary heart disease. Clin Cardiol 2009; 32: E18-E22.

126. Sabatine MS, Morrow DA, de Lemos JA, Jarolim P, Braunwald E. Detection of acute changes in circulating troponin In the setting of transient stress test-induced myocardial ischaemia using an ultrasensitive assay: results from TIMI 35. Eur Heart J 2009; 30: 162-9.

127. Shand JA, Menown IB, MvEneaney DJ. A timely diagnosis of myocardial infarction. Biomarkers Med 2010; 4: 385-93.

128. Glatz JFC, van der Vusse GJ, Simoons ML, Kragten JA, van Dieijen-Visser MP, Hermens WT. Fatty acid-binding protein and the early detection of acute myocardial infarction. Clin Chim Acta 1998; 272: 87-92.

129. Okamoto F, Sohmiya K, Ohkaru $Y$ et al:: Human heart-type cytoplasmic fatty acid-binding protein (H-FABP) for the diagnosis of acute myocardial infarction. clinical evaluation of $\mathrm{H}-\mathrm{FABP}$ in comparison with myoglobin and creatine kinase isoenzyme MB. Clin Chem Lab Med 2000; 38: 231-8.

130. Ecollan $\mathrm{P}$, Collet J, Boon $\mathrm{G}$ et al:: Pre hospital detection of acute myocardial infarction with ultra-rapid human fatty acidbinding protein (H-FABP) immunoassay. Int J Cardiol 2007; 119: 349-54.

131. McCann CJ, Glover BM, Menown I et al. Novel biomarkers in early diagnosis of acute myocardial infarction compared with cardiac troponin T. Eur Heart J 2008; 29: 2843-50.

132. Jones $C B$, Sane DC, Herrington DM. Matrix metalloproteinases: a review of their structure and role in acute coronary syndrome. Cardiovasc Res 2003; 59: 812-23.

133. Brown DL, Hibbs MS, Kearney M, Loushin C, Isner JM. Identification of $92-\mathrm{kD}$ gelatinase in human coronary atherosclerotic lesions: association of active enzyme synthesis with unstable angina. Circulation 1995; 91: 212531.

134. Loftus IM, Naylor AR, Goodall S et al. Increased matrix metalloproteinase-9 activity in unstable carotid plaques: a potential role in acute plaque disruption. Stroke 2000; 31: 40-7.

135. Schönbeck $U$, Libby $P:$ The CD40/CD154 receptor/ligand dyad. Cell Mol Life Sci 2001; 58: 4-43.
136. Henn V, Slupsky JR, Grafe M et al. CD40 ligand on activated platelets triggers an inflammatory reaction of endothelial cells. Nature 1998; 391: 591-4.

137. Lutgens E, Gorelik L, Daemen MJ et an. Requirement for CD154 in the progression of atherosclerosis. Nat Med 1999; 5 : 1313-6.

138. Mach F, Schönbeck U, Sukhova GK, Atkinson E, Libby P: Reduction of atherosclerosis in mice by inhibition of CD 40 signalling. Nature 1998; 394: 200-3.

139. Schonbeck U, Mach F, Sukhova GK et al. Regulation of matrix metalloproteinase expression in human vascular smooth muscle cells by T lymphocytes: a role for CD40 signaling in plaque rupture? Circ Res 1997; 81: 448-54.

140. Graf D, Müller S, Korthäuer U, Kooten CV, Weise C, Kroczek RA. A soluble form of TRAP (CD40 ligand) is rapidly released after T cell activation. Eur J Immunol 1995; 25: 1749-54.

141. Heeschen C, Dimmler S, Hamm C et al: Soluble CD40 ligand in acute coronary syndromes. N Engl J Med 2003; 348: 1104-11.

142. Lawrence JB, Oxvig C, Overgaard MT et al. The insulin-like growth factor (IGF)-dependent IGF binding protein-4 protease secreted by human fibroblasts is pregnancyassociated plasma protein-A. Proc Natl Acad Sci USA 1999; 96: 3149-53.

143. Wald N, Stone R, Cuckle HS et al. First trimester concentrations of pregnancy associated plasma protein $\mathrm{A}$ and placental protein 14 in Down's syndrome. BMJ 1992; 305: 28-28.

144. Bayes-Genis A, Conover CA, Overgaard MT et al. Pregnancyassociated plasma protein $\mathrm{A}$ as a marker of acute coronary syndromes. N Engl J Med 2001; 345: 1022-9.

145. Heeschen C, Dimmeler S, Hamm CW, Fichtlscherer S, Simoons ML, Zeiher AM. Pregnancy-associated plasma protein-A levels in patients with acute coronary syndromes: comparison with markers of systemic inflammation, platelet activation, and myocardial necrosis. J Am Coll Cardiol 2005; 45: 229-37.

146. Keller T, Zeller T, Peetz D et al. Sensitive troponin I assay in early diagnosis of acute myocardial infarction. $\mathrm{N}$ Engl J Med 2009; 361: 868-77.

147. Reichlin T, Hochholzer W, Bassetti $S$ et al. Early diagnosis of myocardial infarction with sensitive cardiac troponin assays. N Engl J Med 2009; 361: 858-67.

148. Apple FS, Smith SW, Pearce LA, Ler R, Murakami MM. Use of the centaur Tnl-ultra assay for detection of myocardial infarction and adverse events in patients presenting with symptoms suggestive of acute coronary syndrome. Clin Chem 2008; 54: 723-8.

149. Mingels A, Jacobs L, Michielsen E, Swaanenburg J, Wodzig W, van Dieijen-Visser M. Reference population and marathon runner sera assessed by highly sensitive cardiac troponin T and commercial cardiac troponin T and I assays. Clin Chem 2009; 55: 101.

150. Melanson SE, Morrow DA, Jarolim P. Earlier detection of myocardial injury in a preliminary evaluation using a new troponin I assay with improved sensitivity. Am J Clin Pathol 2007; 128: 282-6.

151. Gaze DC. High - sensitive cardiac troponin assays: application for prime - time use. Biomarkers Med 2010; 4: 341-3.

152. Twerenbold R, Reichlin T, Mueller C. Clinical application of sensitive cardiac troponin assays: potential and limitations. Biomarkers Med 2010; 4: 395-401.

153. Vasile VC, Saenger AK, Kroning JM, Jaffe AS. Biological and analytical variability of a novel high - sensitivity cardiac troponin T assay. Clin Chem 2010; 56: 1086-90.

154. Johansen JS. Studies on serum YKL-40 as a biomarker in diseases with inflammation, tissue remodelling, fibroses and cancer. Dan. Med. Bull. 2006; 53: 172-209.

155. Johansen JS, Williamson MK, Rice JS, Price PA. Identification 
of proteins secreted by human osteoblastic cells in culture. J. Bone Miner. Res. 1992; 7: 501-12.

156. Hakala BE, White C, Recklies AD. Human cartilage gp-39, a major secretory product of articular chondrocytes and synovial cells, is a mammalian member of a chitinase protein family. J. Biol. Chem. 1993; 268: 25803-10.

157. Morrison BW, Leder P. neu and ras initiate murine mammary tumors that share genetic markers generally absent in c-myc and int-2-initiated tumors. Oncogene 1994; 9: 341726.

158. Shackelton LM, Mann DM, Millis AJ. Identification of a $38-k D a$ heparin-binding glycoprotein (gp38k) in differentiating vascular smooth muscle cells as a member of a group of proteins associated with tissue remodeling. J. Biol. Chem. 1995; 270: 13076-83.

159. Rehli M, Krause SW, Andreesen R. Molecular characterization of the gene for human cartilage gp-39 (CHI3L1), a member of the chitinase protein family and marker for late stages of macrophage differentiation. Genomics 1997; 43: 221-5.

160. Harvey S, Weisman M, O'Dell J et al:: Chondrex: new marker of joint disease. Clin. Chem. 1998; 44: 509-16.

161. Mohanty AK, Singh G, Paramasivam M et al.: Crystal structure of a novel regulatory 40-kDa mammary gland protein (MGP40) secreted during involution. J. Biol. Chem. 2003; 278: 14451-60.

162. Swirski FK, Libby $P$, Aikawa $E$ et al.: Ly-6Chi monocytes dominate hypercholesterolemia-associated monocytosis and give rise to macrophages in atheromata. J. Clin. Invest. 2007; 117: 195-205.

163. Libby P, Braunwald E: Braunwald's Heart Disease (8th Edition). A Textbook of Cardiovascular Medicine. 2008. Saunders/ Elsevier, PA, USA.

164. Baeten D, Boots AM, Steenbakkers PG et al.: Human cartilage gp-39+,CD16+ monocytes in peripheral blood and synovium: correlation with joint destruction in rheumatoid arthritis. Arthritis Rheum. 2000; 43: 1233-43.

165. Kirkpatrick RB, Matico RE, McNulty DE, Strickler JE, Rosenberg M: An abundantly secreted glycoprotein from Drosophila melanogaster is related to mammalian secretory proteins produced in rheumatoid tissues and by activated macrophages. Gene 1995; 153: 147-54.

166. Krause SW, Rehli M, Kreutz M, Schwarzfischer L, Paulauskis JD, Andreesen R: Differential screening identifies genetic markers of monocyte to macrophage maturation. J. Leukoc. Biol. 1996; 60: 540-5.

167. Rehli M, Niller $\mathrm{HH}$, Ammon $\mathrm{C}$ et al:: Transcriptional regulation of CHI3L1, a marker gene for late stages of macrophage differentiation. J. Biol. Chem. 2003; 278: 44058-67.

168. Boot RG, van Achterberg TA, van Aken BE et al.: Strong induction of members of the chitinase family of proteins in atherosclerosis: chitotriosidase and human cartilage gp-39 expressed in lesion macrophages. Arterioscler. Thromb. Vasc. Biol. 1999; 19: 687-94.

169. Nojgaard C, Host NB, Christensen IJ et al.: Serum levels of YKL40 increases in patients with acute myocardial infarction. Coron. Artery Dis. 2008; 19: 257-63.

170. Wang Y, Ripa RS, Johansen JS et al.: YKL-40 a new biomarker in patients with acute coronary syndrome or stable coronary artery disease. Scand. Cardiovasc. J. 2008; 42: 295-302.

171. Hedegaard A, Sejersten RR, Johansen JS, Jorgensen E, Kastrup J: Plasma YKL -40 and recovery of left ventricular function after acute myocardial infarction. Scand. J. Clin. Lab. Invest. 2010; 70: 80-6.

172. Kastrup J, Johansen JS, Winkel $P$ et al:: High serum YKL-40 concentration is associated with cardiovascular and allcause mortality in patients with stable coronary artery disease. Eur. Heart J. 2009; 30: 1066-72.

173. Kucur M, Isman FK, Karadag B, Vural VA, Tavsanoglu S: Serum YKL-40 levels in patients with coronary artery disease.
Coron. Artery Dis. 2007; 18: 391-6.

174. Rathcke CN, Raymond I, Kistorp C, Hildebrandt P, Faber J, Vestergaard $\mathrm{H}$ : Low grade inflammation as measured by levels of YKL -40 : association with an increased overall and cardiovascular mortality rate in an elderly population. Int. J. Cardiol. 2009; 143: 35-42.

175. Reichlin T, Hochholzer W, Stelzig C et al. Incremental value of copeptin for rapid rule out of acute myocardial infarction. J Am Coll Cardiol 2009; 54: 60-8.

176. Morsted A, Hoes AW. Clinical epidemiology of heart failure. Heart 2007; 93: 1137-46.

177. Dalzell JR, Jackson CE, McDonagh TA, Gardner RS. Novel biomarkers in heart failure: an overview. Biomarkers Med 2009; 3: 453-63.

178. Tang WH, Francis GS, Morrow DA et al. National Academy of Clinical Biochemistry Laboratory Medicine Practice Guidelines: utilization of cardiac biomarker testing in heart failure. Circulation 2007; 116: E99-E109.

179. ESC guidelines for the diagnosis and treatment of acute and chronic heat failure 2008. the Task Force for the diagnosis and treatment of acute and chronic heart failure 2008 of the European Society of Cardiology. Developed in collaboration with the Heart Failure Association and endorsed by the European Society of Intensive Care Medicine. Eur. Heart J.2008; 29: 2388-442.

180. Bartunek J. Biomarkers: old - new, cardiac - noncardiac, all paving the way for better stratification in heart failure. Biomarkers Med 2009; 3: 435-7.

181. Vanderheyden M, Vrints C, Verstreken S, Beunk J, Goethals M. B - type batriuretic peptide as a marker of heart failure: new insights from biochemistry and clinical implications. Biomarkers Med 2010; 4: 315-20.

182. Buchner $S$, Jungbauer $C$, Birner C, Debl K, Riegger GA, Luchner A. Comparison of the cardiac markers $B$ - type natriuretic peptide and $\mathrm{N}$ - terminal pro $\mathrm{B}$ - type natriuretic peptide. Biomarkers Med 2009; 3: 465-81.

183. Karmpaliotis D, Kirtane AJ, Ruisi CP et al. Diagnostic and prognostic utility of brain natriuretic peptide in subjects admitted to the ICU with hypoxic respiratory failure due to noncardiogenic and cardiogenic pulmonary edema. Chest 2007; 131: 964-71.

184. KucherN, Goldhaber SZ. Cardiac biomarkers for risk stratification of patients with acute pulmonary embolism. Circulation 2003; 108: 2191-4.

185. Grabowski M, Filipiak KJ, Malek LA et al. Admission B-type natriuretic peptide assessment improves early risk stratification by Killip classes and TIMI risk score in patients with acute ST elevation myocardial infarction treated with primary angioplasty. Int. J. Cardiol. 2007; 115: 386-90.

186. Charpentier J, Luyt CE, Fulla $Y$ et al. Brain natriuretic peptide: a marker of myocardial dysfunction and prognosis during severe sepsis. Crit. Care Med. 2004; 32: 660-5.

187. McLean AS, Huang SJ, Hyams S et al. Prognostic values of B-type natriuretic peptide in severe sepsis and septic shock. Crit. Care Med. 2007; 35: 1019-26.

188. Gardner RS, Chong KS, McDonagh TA: B-type natriuretic peptides in heart failure. Biomark. Med. 2007; 1: 243-50.

189. Gegenhuber A, Struck J, Poelz W et al.: Midregional pro-Atype natriuretic peptide measurements for diagnosis of acute destabilized heart failure in short-of-breath patients: comparison with B-type natriuretic peptide (BNP) and amino-terminal proBNP. Clin. Chem. 2006; 52: 827-31.

190. Von Haehling S, Jankowska EA, Morgenthaer NG, et al. Comparison of midregional pro - atrial natriuretic peptide with $\mathrm{N}$ - terminal pro - B - type batriuretic peptide in predicting survival in patients with chronic heart failure. $\mathrm{J}$ Am Coll Cardiol 2007; 50: 1973-80.

191. Moertl D, Berger R, Struck J, et al. Comparison of midregional pro - ANP and B - type natriuretic peptides in chronic heart 
failure. J Am Coll Cardiol 2009; 53: 1783-90.

192. Elmas E, Brueckmann M, Lang $S$ et al.: Midregional pro-atrial natriuretic peptide is a useful indicator for the detection of impaired left ventricular function in patients with coronary artery disease. Int. J. Cardiol. 2008; 128: 244-9.

193. Bunton DC, Petrie MC, Hillier C, Johnston F, McMurray JJ: The clinical relevance of adrenomedullin: a promising profile? Pharmacol. Ther. 2004; 103: 179-201.

194. Pousset F, Masson F, Chavirovskaia $O$ et al: Plasma adrenomedullin, a new independent predictor of prognosis in patients with chronic heart failure. Eur. Heart J. 2000; 21: 1009-14.

195. Morgenthaler NG, Struck J, Alonso C, Bergmann A: Measurement of midregional proadrenomedullin in plasma with an immunoluminometric assay. Clin. Chem. 2005; 51 : 1823-9.

196. Elmas E, Lang S, Dempfle CE et al.: Diagnostic performance of mid-regional pro-adrenomedullin as an analyte for the exclusion of left ventricular dysfunction. Int. J. Cardiol. 2008; 128: 107-111.

197. Khan SQ, O'Brien RJ, Struck J et al:: Prognostic value of midregional pro-adrenomedullin in patients with acute myocardial infarction: the LAMP (Leicester Acute Myocardial Infarction Peptide) study. J. Am. Coll. Cardiol. 2007; 49: 1525-32.

198. Adlbrecht C, Hülsmann M, Strunk G et al.: Prognostic value of plasma midregional pro-adrenomedullin and C-terminalpro-endothelin-1 in chronic heart failure outpatients. Eur. J Heart Fail. 2009; 11: 361-6.

199. Finley JJ 4th, Konstam MA, Udelson JE: Arginine vasopressin antagonists for the treatment of heart failure and hyponatremia. Circulation 2008; 118: 410-21.

200. Goldsmith SR, Francis GS, Cowley AW Jr, Levine TB, Cohn JN: Increased plasma arginine vasopressin levels in patients with congestive heart failure. J. Am. Coll. Cardiol. 1983; 1: 1385-90.

201. Morgenthaler NG, Struck J, Alonso C, Bergmann A: Assay for the measurement of copeptin, a stable peptide derived from the precursor of vasopressin. Clin. Chem. 2006; 52: $112-9$.

202. Khan SQ, Dhillon OS, O'BrienRJetal:: C-terminal provasopressin (copeptin) as a novel and prognostic marker in acute myocardial infarction: Leicester Acute Myocardial Infarction Peptide (LAMP) study. Circulation 2007; 115: 2103-10.

203. Kelly D, Squire IB, Khan SQ et al.: C-terminal provasopressin (copeptin) is associated with left ventricular dysfunction, remodeling, and clinical heart failure in survivors of myocardial infarction. J. Card. Fail. 2008; 14: 739-45.

204. Voors AA, von Haehling S, Anker SD et al:: C-terminal provasopressin (copeptin) is a strong prognostic marker in patients with heart failure after an acute myocardial infarction: results from the OPTIMAAL study. Eur. Heart J. 2009; 30: 1187-94.

205. Gegenhuber A, Struck J, Dieplinger B et al:: Comparative evaluation of B-type natriuretic peptide, mid-regional pro-Atype natriuretic peptide, mid-regional pro-adrenomedullin, and copeptin to predict 1-year mortality in patients with acute destabilized heart failure. J. Card. Fail. 2007; 13: 42-9.

206. Stoiser B, Mörtl D, Hülsmann M et al:: Copeptin, a fragment of the vasopressin precursor, as a novel predictor of outcome in heart failure. Eur. J. Clin. Invest. 2006; 36: 771-8.

207. Neuhold S, Huelsmann M, Strunk $G$ et al:: Comparison of copeptin, B-type natriuretic peptide, and amino-terminal pro-B-type natriuretic peptide in patients with chronic heart failure: prediction of death at different stages of the disease. J. Am. Coll. Cardiol. 2008; 52: 266-72.

208. Helle KB: The granin family of uniquely acidic proteins of the diffuse neuroendocrine system: comparative and functional aspects. Biol. Rev. Camb. Philos. Soc. 2004; 79: 769-94.

209. Pieroni M, Corti A, Tota B et al:: Myocardial production of chromogranin $A$ in human heart: a new regulatory peptide of cardiac function. Eur. Heart J. 2007; 28: 1117-27.

210. Taupenot L, Harper KL, O'Connor DT: The chromograninsecretogranin family. N. Engl. J. Med. 2003; 348: 1134-49.

211.Ceconi C, Ferrari R, Bachetti T et al.: Chromogranin A in heart failure; a novel neurohumoral factor and a predictor for mortality. Eur. Heart J. 2002; 23: 967-74.

212. Dieplinger B, Gegenhuber A, Struck J et al.: Chromogranin $A$ and $C$-terminal endothelin-1 precursor fragment add independent prognostic information to amino-terminal proBNP in patients with acute destabilized heart failure. Clin. Chim. Acta 2009; 400: 91-6.

213. Kleinz MJ, Davenport AP: Immunocytochemical localization of the endogenous vasoactive peptide apelin to human vascular and endocardial endothelial cells. Regul. Pept. 2004; 118: 119-25.

214. O'Dowd BF, Heiber M, Chan A et al.: A human gene that shows identity with the gene encoding the angiotensin receptor is located on chromosome 11. Gene 1993; 136: 355-60.

215. Lee DK, Cheng R, Nguyen T et al.: Characterization of apelin, the ligand for the APJ receptor. J. Neurochem. 2000; 74: $34-41$.

216. Tatemoto K, Takayama K, Zou MX et al.: The novel peptide apelin lowers blood pressure via a nitric oxide dependent mechanism. Regul. Pept. 2001; 99: 87-92.

217. Jia YX, Lu ZF, Zhang $J$ et al:: Apelin activates I-arginine/nitric oxide synthase/nitric oxide pathway in rat aortas. Peptides 2007; 28: 2023-9.

218. Japp AG, Cruden NL, Amer DA et al.: Vascular effects of apelin in vivo in man. J. Am. Coll. Cardiol. 2008; 52: 908-13.

219. De Mota N, Reaux-Le Goazigo A, El Messari S et al:: Apelin, a potent diuretic neuropeptide counteracting vasopressin actions through inhibition of vasopressin neuron activity and vasopressin release. Proc. Natl Acad. Sci. USA 2004; 101: 10464-9.

220. Hus-Citharel A, Bouby N, Frugière A, Bodineau L, Gasc JM, Llorens-Cortes C: Effect of apelin on glomerular hemodynamic function in the rat kidney. Kidney Int. 2004; 74: 486-94.

221. Ernst KV, Ashley EA, Charo D et al.: Apelin regulates cardiac contractility and rescues neurohormonal heart failure. Circulation 2006; 114 (Abstract II_66).

222. Szokodi I, Tavi P, Foldes $G$ et al:: Apelin, the novel endogenous ligand of the orphan receptor APJ, regulates contractility. Circ. Res. 2002; 91: 434-400.

223. Farkasfalvi K, Stagg MA, Coppen SR et al.: Direct effects of apelin on cardiomyocyte contractility and electrophysiology. Biochem. Biophys. Res. Comm. 2007; 357: 889-95.

224. Jia YX, Pan CS, Zhang J et al.: Apelin protects myocardial injury induced by isoproterenol in rats. Regul. Pept. 2006; 133: 147-54.

225. Berry MF, Pirolli TJ, Jayasankar $V$ et al.: Apelin has in vivo inotropic effects on normal and failing hearts. Circulation 2004; 110(Suppl. 11): 187-93.

226. Ashley EA, Powers J, Chen $M$ et al:: The endogenous peptide apelin potently improves cardiac contractility and reduces cardiac loading in vivo. Cardiovasc. Res. 2005; 65: 73-82.

227. Kuba K, Zhang L, Imai $Y$ et al.: Impaired heart contractility in apelin gene-deficient mice associated with aging and pressure overload. Circ. Res. 2007; 101: E32-E42.

228. WeirRA, ChongKS, DalzellJRet al.: Plasmaapelin concentration is depressed following acute myocardial infarction in man. Eur. J. Heart Fail. 2009; 11: 551-8.

229. Chong KS, Gardner RS, Morton JJ, Ashley EA, McDonagh TA: Plasma concentrations of the novel peptide apelin are decreased in patients with chronic heart failure. Eur. J. 
Heart Fail. 2006; 8: 355-60.

230. Chen MM, Ashley EA, Deng DX et al.: Novel role for the potent endogenous inotrope apelin in human cardiac dysfunction. Circulation 2003; 108: 1432-39.

231. Francia $P$, Salvati $A$, Balla $C$ et al.: Cardiac resynchronization therapy increases plasma levels of the endogenous inotrope apelin. Eur. J. Heart Fail. 2007; 9: 306-9.

232. Goetze JP, ReCHFeld JF, Carlsen J et al.: Apelin: a new plasma marker of cardiopulmonary disease. Regul. Pept. 2006; 133: $134-8$.

233. Földes G, Horkay F, Szokodi I et al:: Circulating and cardiac levels of apelin, the novel ligand of the orphan receptor APJ, in patients with heart failure. Biochem. Biophys. Res. Commun. 2003; 308: 480-5.

234. Mullens W, Bartunek J, Wilson Tang WH et al.: Early and late effects of cardiac resynchronization therapy on forcefrequency relation and contractility regulating gene expression in heart failure patients. Heart Rhythm 2008; 5 : $52-9$.

235. Burnett JC Jr: Urocortin, advancing the neurohumoral hypothesis of heart failure. Circulation 2005; 112: 3544-6.

236. Parkes DG, Vaughan J, Rivier J, Vale W, May CN: Cardiac inotropic actions of urocortin in conscious sheep. Am. J. Physiol. 1997; 272: H2115-22.

237. Chen ZW, Huang Y, Yang Q, Li X, Wei W, He GW: Urocortininduced relaxation in the human internal mammary artery. Cardiovasc. Res. 2005; 65: 913-20.

238. Sanz E, Monge L, Fernández $N$ et al.: Relaxation by urocortin of human saphenous veins. Br. J. Pharmacol. 2002; 136: 90-4.

239. Nishikimi T, Miyata A, Horio $T$ et al.: Urocortin, a member of the corticotropin-releasing factor family, in normal and diseased heart. Am. J Physiol. Heart Circ. Physiol. 2000; 279: $\mathrm{H} 3031-9$.

240. Ikeda K, Tojo K, Sato $S$ et al:: Urocortin, a newly identified corticotropin-releasing factor-related mammalian peptide, stimulates atrial natriuretic peptide and brain natriuretic peptide secretions from neonatal rat cardiomyocytes. Biochem. Biophys. Res. Commun. 1998; 250: 298-304.

241. Rademaker MT, Charles CJ, Espiner EA, Frampton CM, Lainchbury JG, Richards AM: Four-day urocortin-I administration has sustained beneficial haemodynamic, hormonal, and renal effects in experimental heart failure. Eur. Heart J. 2005; 26: 2055-62.

242. Rademaker MT, Cameron VA, Charles CJ, Richards AM: Integrated hemodynamic, hormonal, and renal actions of urocortin 2 in normal and paced sheep: beneficial effects in heart failure. Circulation 2005; 112: 3624-32.

243. Rademaker MT, Cameron VA, Charles CJ, Richards AM: Urocortin 3: haemodynamic, hormonal, and renal effects in experimental heart failure. Eur. Heart J. 2006; 27: 208898.

244. Bale TL, Hoshijima M, GuY et al.: The cardiovascular physiologic actions of urocortin II: acute effects in murine heart failure. Proc. Natl Acad. Sci. USA 2004; 101: 3697-3702.

245. Rademaker MT, Charles CJ, Richards AM: Urocortin 1 administration from onset of rapid left ventricular pacing represses progression to overt heart failure. Am. J. Physiol. Heart Circ. Physiol. 2007; 293: H1536-44.

246. Ng LL, Loke IW, O'Brien RJ, Squire IB, Davies JE: Plasma urocortin in human systolic heart failure. Clin. Sci. 2004; 106: 383-8.

247. Crane FL, Hatefi Y, Lester RL, Widmer C: Isolation of a quinone from beef heart mitochondria. Biochim. Biophys. Acta 1957; 25: $220-1$.

248. Folkers K, Vadhanavikit S, Mortensen SA: Biochemical rationale and myocardial tissue data on the effective therapy of cardiomyopathy with coenzyme Q10. Proc. Natl Acad. Sci.
USA 1985; 82: 901-4.

249. Molyneux SL, Florkowski CM, George PM et al: Coenzyme Q10: an independent predictor of mortality in chronic heart failure. J. Am. Coll. Cardiol. 2008; 52: 1435-41.

250. Sander S, Coleman $\mathrm{Cl}$, Patel AA, Kluger J, White CM: The impact of coenzyme Q10 on systolic function in patients with chronic heart failure. J. Card. Fail. 2006; 12: 464-72.

251. Mortensen SA: Overview on coenzyme Q10 as adjunctive therapy in chronic heart failure. Rationale, design and endpoints of "Q-symbio" - a multinational trial. Biofactors 2003; 18: 79-89.

252. Hopkins TA, Ouchi N, Shibata R, Walsh K: Adiponectin actions in the cardiovascular system. Cardiovasc. Res. 2007; 74: $11-8$.

253. Fujioka D, Kawabata K, Saito $Y$ et al.: Role of adiponectin receptors in endothelin-induced cellular hypertrophy in cultured cardiomyocytes and their expression in infracted heart. Am. J Physiol. Heart Circ. Physiol. 2006; 290: H2409-16.

254. Dieplinger B, Gegenhuber A, Poelz W, Haltmayer M, Mueller T: Prognostic value of increased adiponectin plasma concentrations in patients with acute destabilized heart failure. Clin. Biochem 2009; .42: 1190-3.

255. Tanaka $\mathrm{T}$, Tsutamoto $\mathrm{T}$, Sakai $\mathrm{H}$ et al:: Effect of atrial natriuretic peptide on adiponectin in patients with heart failure. Eur. J. Heart Fail. 2008; 10: 360-6.

256. Kistorp C, Faber J, Galatius S et al.: Plasma adiponectin, body mass index, and mortality in patients with chronic heart failure. Circulation 2005; 112: 1756-62.

257. Mann DL: Inflammatory mediators and the failing heart: past, present, and the foreseeable future. Circ. Res. 2002; 91: 988-98.

258. Yanagisawa K, Tsukamoto T, Takagi T, Tominaga S: Murine ST2 gene is a member of the primary response gene family induced by growth factors. FEBS Lett. 1992; 302: 51-3.

259. Townsend MJ, Fallon PG, Matthews DJ, Jolin HE, McKenzie AN: T1/ST2-deficient mice demonstrate the importance of T1/ ST2 in developing primary T helper cell type 2 responses. J. Exp. Med. 2000; 191: 1069-76.

260. Weinberg EO, Shimpo M, De Keulenaer GW et al.: Expression and regulation of ST2, an interleukin-1 receptor family member, in cardiomyocytes and myocardial infarction. Circulation 2002; 106: 2961-6.

261. Schmitz J, Owyang A, Oldham E et al: IL-33, an interleukin-1like cytokine that signals via the IL-1 receptor-related protein ST2 and induces T helper type 2-associated cytokines. Immunity. 2005; 23: 479-90.

262. Sanada S, Hakuno D, Higgins LJ, Schreiter ER, McKenzie AN, Lee RT: IL-33 and ST2 comprise a critical biomechanically induced and cardioprotective signaling system. J. Clin. Invest. 2007; 117: 1538-49.

263. Sabatine MS, Morrow DA, Higgins LJ et al.: Complementary roles for biomarkers of biomechanical strain ST2 and N-terminal prohormone B-type natriuretic peptide in patients with ST-elevation myocardial infarction. Circulation 2008; 117 : 1936-44.

264. Boisot S, Beede J, Isakson S et al.: Serial sampling of ST2 predicts 90 -day mortality following destabilized heart failure. J. Card. Fail. 2008; 14: 7328.

265. Rehman SU, Mueller T, Januzzi JL Jr: Characteristics of the novel interleukin family biomarker ST2 in patients with acute heart failure. J. Am. Coll. Cardiol. 2008; 52: 1458-65.

266. Januzzi JL Jr, Peacock WF, Maisel AS et al:: Measurement of the interleukin family member ST2 in patients with acute dyspnea: results from the PRIDE (Pro-Brain Natriuretic Peptide Investigation of Dyspnea in the Emergency Department) study. J. Am. Coll. Cardiol. 2007; 50: 607-13.

267. Mueller T, Dieplinger B, Gegenhuber A, Poelz W, Pacher R, 
Haltmayer M: Increased plasma concentrations of soluble ST2 are predictive for 1-year mortality in patients with acute destabilized heart failure. Clin. Chem. 2008; 54: 752-6.

268. Weinberg EO, Shimpo M, Hurwitz S, Tominaga S, Rouleau JL, Lee RT: Identification of serum soluble ST2 receptor as a novel heart failure biomarker. Circulation 2003; 107: $721-6$.

269. Kempf $\mathrm{T}$, Eden $\mathrm{M}$, Strelau $\mathrm{J}$ et al: The transforming growth factor- $\beta$ superfamily member growth-differentiation factor15 protects the heart from ischemia/reperfusion injury. Circ. Res. 2006; 98: 351-60.

270. Xu J, Kimball TR, Lorenz JN et al.: GDF15/MIC-1 functions as a protective and antihypertrophic factor released from the myocardium in association with SMAD protein activation. Circ. Res. 2006; 98: 342-50.

271. Kempf T, von Haehling S, Peter T et al:: Prognostic utility of growth differentiation factor-15 in patients with chronic heart failure. J. Am. Coll. Cardiol. 2007; 50: 1054-60.

272. Garlanda C, Bottazzi B, Bastone A, Mantovani A: Pentraxins at the crossroads between innate immunity, inflammation, matrix deposition and female fertility. Annu. Rev. Immunol. 2005; 23: 337-66.

273. Latini R, Maggioni AP, Peri G et al.: Prognostic significance of the long pentraxin PTX3 in acute myocardial infarction. Circulation 2004; 110: 2349-54.

274. Suzuki S, Takeishi $Y$, Niizeki $T$ et al: Pentraxin 3, a new marker for vascular inflammation, predicts adverse clinical outcomes in patients with heart failure. Am. Heart J. 2008; 155: 75-81.

275. Kotooka N, Inoue T, Aoki S, Anan M, Komoda H, Node K: Prognostic value of pentraxin 3 in patients with chronic heart failure. Int. J. Cardiol. 2008; 130: 19-22.

276. Xie Z, Pimental DR, Lohan S et al.: Regulation of angiotensin IIstimulated osteopontin expression in cardiac microvascular endothelial cells: role of $p 42 / 44$ mitogen-activated protein kinase and reactive oxygen species. J. Cell. Physiol. 2001; 188: $132-8$.

277. Singh K, Sirokman G, Communal C et al.: Myocardial osteopontin expression coincides with the development of heart failure. Hypertension 1999; 33: 663-70.

278. Xie Z, Singh M, Singh K: Osteopontin modulates myocardial hypertrophy in response to chronic pressure overload in mice. Hypertension 2004; 44: 826-31.

279. Kramer F, Sandner $P$, Klein M, Krahn T: Plasma concentrations of matrix metalloproteinase-2, tissue inhibitor of metalloproteinase-1 and osteopontin reflect severity of heart failure in DOCA-salt hypertensive rat. Biomarkers 2008; 13: 270-81.

280. Stawowy P, Blaschke F, Pfautsch P et al:: Increased myocardial expression of osteopontin in patients with advanced heart failure. Eur. J. Heart Fail. 2002; 4: 139-46.

281. Satoh M, Nakamura M, Akatsu T, Shimoda Y, Segawa I, Hiramori $\mathrm{K}$ : Myocardial osteopontin expression is associated with collagen fibrillogenesis in human dilated cardiomyopathy. Eur. J. Heart Fail. 2005; 7: 755-62.

282. Rosenberg $M$, Zugck $C$, Nelles $M$ et al:: Osteopontin, a new prognostic biomarker in patients with chronic heart failure. Circ. Heart Fail. 2008; 15: 43-9.

283. Pennica D, Swanson TA, Shaw KJ et al.: Human cardiotrophin-1: protein and gene structure, biological and binding activities, and chromosomal localization. Cytokine 1996; 8: 183-9.

284. Pemberton CJ, Raudsepp SD, Yandle TG, Cameron VA, Richards AM: Plasma cardiotrophin-1 is elevated in human hypertension and stimulated by ventricular stretch. Cardiovasc. Res. 2005; 68: 109-17.

285. Zolk O, Engmann S, Münzel F, Krajcik R: Chronic cardiotrophin-1 stimulation impairs contractile function in reconstituted heart tissue. Am. J. Physiol. Endocrinol. Metab. 2005; 288: E1214-21.
286. Jin H, Yang R, Keller GA et al.: In vivo effects of cardiotrophin-1. Cytokine 1996; 8: 920-6.

287. Tsutamoto T, Wada A, Maeda $\mathrm{K}$ et al:: Relationship between plasma level of cardiotrophin-1 and left ventricular mass index in patients with dilated cardiomyopathy. J. Am. Coll. Cardiol. 2001; 38: 1485-90.

288. Tsutamoto T, Asai S, Tanaka T et al.: Plasma level of cardiotrophin-1 as a prognostic predictor in patients with chronic heart failure. Eur. J. Heart Fail. 2007; 9: 1032-7.

289. Li Y, Komai-Koma M, Gilchrist DS et al.: Galectin-3 is a negative regulator of lipopolysaccharide-mediated inflammation. J. Immunol. 2008; 181: 2781-9.

290. Abrahamson M, Olafsson I, Palsdottir A et al.: Structure and expression of the human cystatin $\mathrm{C}$ gene. Biochem. J. 1990; 268: 287-94.

291. Lassus J, Harjola VP, Sund R et al.: Prognostic value of cystatin $\mathrm{C}$ in acute heart failure in relation to other markers of renal function and NT-proBNP. Eur. Heart J. 2007; 28: 1841-7.

292. Ix JH, Shlipak MG, Chertow GM, Whooley MA: Association of cystatin C with mortality, cardiovascular events, and incident heart failure among persons with coronary heart disease: data from the Heart and Soul Study. Circulation 2007; 115: 173-9.

293. Arimoto T, Takeishi Y, Niizeki T et al.: Cystatin C, a novel measure of renal function, is an independent predictor of cardiac events in patients with heart failure. J. Card. Fail 2005; 11: 595-601.

294. Shlipak MG, Katz R, Fried LF et al.: Cystatin-C and mortality in elderly persons with heart failure. J. Am. Coll. Cardiol. 2005; 45: 268-71.

295. Jackson CE, Dalzell JR, Gardner RS. Prognostic utility of cardiac troponin in heart failure: a novel role for an established biomarker. Biomarkers 2009; 3: 483-93.

296. Gros R, Benovic JL, Tan CM, Feldman RD: G-protein-coupled receptor kinase activity is increased in hypertension. J. Clin. Invest. 1997; 99: 2087-93.

297. Usui I, Imamura T, Satoh H et al.: GRK2 is an endogenous protein inhibitor of the insulin signaling pathway for glucose transport stimulation. EMBO J. 2004; 23: 2821-9.

298. Ungerer M, Böhm M, Elce JS, Erdmann E, Lohse MJ: Altered expression of $\beta$-adrenergic receptor kinase and $\beta 1$ adrenergic receptors in the failing human heart. Circulation 1993; 87: 454-63.

299. Cross HR, Steenbergen C, Lefkowitz RJ, Koch WJ, Murphy E: Overexpression of the cardiac $\beta 2$-adrenergic receptor and expression of a $\beta$-adrenergic receptor kinase-1 (BARK1) inhibitor both increase myocardial contractility but have differential effects on susceptibility to ischemic injury. Circ. Res. 1999; 85: 1077-84.

300. laccarino G, Koch WJ: Therapeutic potential of G-protein coupled receptor kinases in the heart. Expert Opin. Investig. Drugs 1999; 8: 545-54.

301. Penela P, Murga C, Ribas C, Tutor AS, Peregrín S, Mayor F $\mathrm{Jr}$ : Mechanisms of regulation of $\mathrm{G}$ protein-coupled receptor kinases (GRKs) and cardiovascular disease. Cardiovasc. Res. 2006; 69: 46-56.

302. laccarino G, Barbato E, Cipolletta E et al.: Elevated myocardial and lymphocyte GRK2 expression and activity in human heart failure. Eur. Heart J. 2005; 26: 1752-8.

303. Dzimiri N, Basco C, Moorji A, Afrane B, Al-Halees Z: Characterization of lymphocyte $\beta 2$-adrenoceptor signalling in patients with left ventricular volume overload disease. Clin. Exp. Pharmacol. Physiol. 2002; 29: 181-8.

304. Park SJ, Choi DJ, Kim CW: Hypertensive left ventricular hypertrophy: relation to $\beta$-adrenergic receptor kinase-1 ( $\beta A R K 1$ ) in peripheral lymphocytes. J. Hypertens. 2004; 22: 1025-32.

305. Hata JA, Williams ML, Schroder JN et al.: Lymphocyte levels 
of GRK2 ( $\beta A R K 1)$ mirror changes in the LVAD-supported failing human heart: lower GRK2 associated with improved $\beta$-adrenergic signaling after mechanical unloading. J. Card. Fail. 2006; 12: 360-8.

306. Campanile A, laccarino G. G-protein-coupled receptor kinases in cardiovascular conditions: focus on G-protein -coupled receptor kinase 2 , a gain in translational medicine. Biomarkers Med 2009; 3: 525-40.

307. Bhaila V, Kalogeropoulos A, Georgiopoulou V, Butler J. Serum resistin: physiology, patophysiology, and implications for geart failure. Biomarkers Med 2010; 4: 44552.

308. DeardorffR, Spinale FG. Cytokinesand matrixmetalloproteinases as potential biomarkers in chronic heart failure. Biomarkers Med 2009; 3: 51323.

309. Rauchhaus M, Doehner W, Francis DP et al.: Plasma cytokine parameters and mortality in patients with chronic heart failure. Circulation 2000; 102:3060-7.

310. Noji $\mathrm{Y}$, Shimizu M, Ino $\mathrm{H}$ et al.: Increased circulating matrix metalloproteinase-2 in patients with hypertrophic cardiomyopathy with systolic dysfunction. Circ. J. 2004; 68 : $355-60$.

311. Frantz S, Stork S, Michels $\mathrm{K}$ et al:: Tissue inhibitor of metalloproteinases levels in patients with chronic heart failure: an independent predictor of mortality. Eur. J. Heart Fail. 2008; 10: 388-95.

312. Lommi J, Pulkki K, Koskinen $P$ et al.: Haemodynamic, neuroendocrine and metabolic correlates of circulating cytokine concentrations in congestive heart failure. Eur. Heart J. 1997; 18: 1620-5.

313. Deswal A, Petersen NJ, Feldman AM, Young JB, White BG, Mann DL: Cytokines and cytokine receptors in advanced heart failure: an analysis of the cytokine database from the Vesnarinone trial (VEST). Circulation 2001; 103: 2055-9.

314. Ferrari R, Bachetti $\mathrm{T}$, Confortini $\mathrm{R}$ et al: Tumor necrosis factor soluble receptors in patients with various degrees of congestive heart failure. Circulation 1995; 92: 1479-86.

315. Kelly $D$, Khan SQ, Thompson $M$ et al.: Plasma tissue inhibitor of metalloproteinase-1 and matrix metalloproteinase-9: novel indicators of left ventricular remodelling and prognosis after acute myocardial infarction. Eur. Heart J. 2008; 29: 211624.

316. Valgimigli $\mathrm{M}$, Ceconi $\mathrm{C}$, Malagutti $\mathrm{P}$ et al.: Tumor necrosis factor- $\alpha$ receptor 1 is a major predictor of mortality and new-onset heart failure in patients with acute myocardial infarction: the Cytokine-Activation and Long-Term Prognosis in Myocardial Infarction (C-ALPHA) study. Circulation 2005; 111: 863-70.

317. Lopez B, GonzalezA, Querejeta R, Larman M, Diez J:Alterations in the pattern of collagen deposition may contribute to the deterioration of systolic function in hypertensive patients with heart failure. J. Am. Coll. Cardiol. 2006; 48: 89-96.

318. Niethammer M, Sieber M, von Haehling $S$ et al.: Inflammatory pathways in patients with heart failure and preserved ejection fraction. Int. J. Cardiol. 2008; 129: 111-7.

319. Go AS, Hylek EM, Phillips KA, et al. Prevalence of diagnosed atrial fibrillation in adults: national implications for rhythm management and stroke prevention: the AnTicoagulation and Risk Factors in Atrial Fibrillation (ATRIA) Study. JAMA. 2001;285:2370-5

320. Miyasaka Y, Barnes ME, Gersh BJ, et al. Secular trends in incidence of atrial fibrillation in Olmsted County, Minnesota, 1980 to 2000 , and implications on the projections for future prevalence. Circulation. 2006;114:119-25.

321. Friberg J, Buch P, Scharling H, Gadsbphioll N, Jensen GB. Rising rates of hospital admissions for atrial fibrillation. Epidemiology. 2003;14: 666-72.

322. Stewart S, Hart CL, Hole DJ, McMurray JJ. Population prevalence, incidence, and predictors of atrial fibrillation in the Renfrew/Paisley study. Heart. 2001;86:516-21.

323. Reynolds MR, Lavelle T, Essebag V, Cohen DJ, Zimetbaum P.
Influence of age, sex, and atrial fibrillation recurrence on quality of life outcomes in a population of patients with newonset atrial fibrillation: the Fibrillation Registry Assessing Costs, Therapies, Adverse events and Lifestyle (FRACTAL) study. Am Heart J. 2006;152:1097-103.

324. Benjamin EJ, Wolf PA, D'Agostino RB, Silbershatz H, Kannel WB, Levy D. Impact of atrial fibrillation on the risk of death: the Framingham Heart Study. Circulation. 1998;98:946 -52 .

325. Wolf PA, Mitchell JB, Baker CS, Kannel WB, D'Agostino RB. Impact of atrial fibrillation on mortality, stroke, and medical costs. Arch Intern Med. 1998;158:229-34.

326. Wattigney WA, Mensah GA, Croft JB. Increasing trends in hospitalization for atrial fibrillation in the United States, 1985 through 1999: implications for primary prevention. Circulation. 2003;108:711-6.

327. Benjamin EJ, Levy D, Vaziri SM, D'Agostino RB, Belanger AJ, Wolf PA. Independent risk factors for atrial fibrillation in a population-based cohort: the Framingham Heart Study. JAMA. 1994;271:840-4.

328. Krahn AD, Manfreda J, Tate RB, Mathewson FA, Cuddy TE. The natural history of atrial fibrillation: incidence, risk factors, and prognosis in the Manitoba Follow-Up Study. Am J Med. 1995;98:476-84.

329. Wolf PA, Benjamin EJ, Belanger AJ, Kannel WB, Levy D, D'Agostino RB. Secular trends in the prevalence of atrial fibrillation: the Framingham Study. Am Heart J. 1996;131:790-5.

330. Schnabel RB, Sullivan LM, Levy D, et al. Development of a risk score for atrial fibrillation (Framingham Heart Study): a community-based cohort study. Lancet. 2009;373:739-45.

331. Liu T, Li G, Li L, Korantzopoulos P. Association between $\mathrm{C}$-reactive protein and recurrence of atrial fibrillation after successful electrical cardioversion: a meta-analysis. J Am Coll Cardiol. 2007;49:1642-718.

332. Mukamal KJ, Tolstrup JS, Friberg J, Gronbaek M, Jensen G. Fibrinogen and albumin levels and risk of atrial fibrillation in men and women (the Copenhagen City Heart Study). Am J Cardiol. 2006;98:75- 81.

333. Wang TJ, Larson MG, Levy D, et al. Plasma natriuretic peptide levels and the risk of cardiovascular events and death. $\mathrm{N}$ Engl J Med. 2004;350:655-63.

334. Dixen U, Ravn L, Soeby-Rasmussen C, et al. Raised plasma aldosterone and natriuretic peptides in atrial fibrillation. Cardiology. 2007;108:35-9.

335. Marcucci R, Betti I, Cecchi E, et al. Hyperhomocysteinemia and vitamin B6 deficiency: new risk markers for nonvalvular atrial fibrillation? Am Heart J. 2004;148:456-61.

336. Marin F, Roldan V, Climent VE, et al. Plasma von Willebrand factor, soluble thrombomodulin, and fibrin D-dimer concentrations in acute onset non-rheumatic atrial fibrillation. Heart. 2004;90:1162-6.

337. Ikeda U, Yamamoto K, Shimada K. Biochemical markers of coagulation activation in mitral stenosis, atrial fibrillation, and cardiomyopathy. Clin Cardiol. 1997;20:7-10.

338. Asselbergs FW, van den Berg MP, Diercks GF, van Gilst WH, van Veldhuisen DJ. C-reactive protein and microalbuminuria are associated with atrial fibrillation. Int $\mathrm{J}$ Cardiol. 2005;98:73-7.

339. Schnabel RB, Larson MG, Yamamoto JF, et al. Relation of biomarkers of distinct patophysiological pathways and atrial fibrillation incidence in the community. Circulation 2010; 121: $200-7$.

340. Henningsen KM, Therkelsen SK, Johansen JS, Bruunsgaard H, Svendsen JH. Plasma YKL-40, a new biomarker for atrial fibrillation? Europace 2009; 11: 1032-6.

341. Mathiasen BA, Henningsen KMA, Harutyunyan MJ, Myhind ND, Kastrup J. YKL-40: a new biomarker in cardiovascular disease? Biomarkers Med 2010; 4: 591-600. 